Boise State University

ScholarWorks

Economics Faculty Publications and Presentations

Department of Economics

$12-1-2015$

\title{
Young in Class: Implications for Inattentive/ Hyperactive Behaviour of Canadian Boys and Girls
}

Kelly Chen

Boise State University

Nicole Fortin

University of British Columbia

Shelley Phipps

Dalhousie University 


\title{
Young in Class: Implications for Inattentive/Hyperactive Behaviour of Canadian Boys and Girls
}

\author{
Kelly Chen \\ Department of Economics \\ College of Business and Economics \\ Boise State University \\ Nicole Fortin \\ Vancouver School of Economics \\ University of British Columbia \\ Canadian Institute for Advanced Research \\ Shelley Phipps \\ Department of Economics \\ Dalhousie University \\ Canadian Institute for Advanced Research
}

\begin{abstract}
Using data from the Statistics Canada National Longitudinal Survey of Children and Youth (NLSCY), this paper investigates the impact of school entry age on inattentive/hyperactive behaviours. We employ both a cross-provinces-time differences-in-differences approach, and a within-province regression discontinuity design. We find that being young in class causes greater inattentive/hyperactive behaviour, exacerbating any inattentive/hyperactive behavior exhibited prior to school entry. These results also also hold in sibling fixed effect models. Though we do not find gender differences in the effects, because boys are more likely to be inattentive/hyperactive at school entry, they are more affected. These effects persist into early adolescence.
\end{abstract}

Sommaire. Nous utilisons les données de Enquête longitudinale nationale sur les enfants et les jeunes (ELNEJ) pour étudier l'impact de l'âge d'entrée à l'école sur les comportements d'inattention et d'hyperactivité. Nous tirons advantage des différences interprovinciales, qui varient dans le temps, dans le cadre d'une approche de différences-en-différences et nous utilisons aussi des régressions de discontinuité à l'interieur des provinces. Nos résultats démontrent qu'être relativement jeune dans la classe augmente les comportements inattentifs et hyperactifs, spécialement chez les jeunes déjà inattentifs/hyperactifs avant l'entrée à l'école. Ces résultats tiennent également dans des modèles à effets fixes familiaux. Bien que les effets ne soient pas différents entre garçons et filles, parce que les garçons sont plus susceptibles d'être inattentifs/hyperactifs avant d'entrer à l'école, ils sont aussi les plus touchés. Ces effets persistent en début d'adolescence.

JEL classification: J13, I20

This research is being conducted as part of the Canadian Institute for Advanced Research (CIFAR) Programme on Social Interactions, Identity and Well-Being. The NLSCY data were access through the Atlantic Research Data Centre; we thank Heather Hobson for vetting our output. 
This is an author-produced, peer-reviewed version of this article. The final, definitive version of this document can be found online at Canadian Journal of Economics. Published by Wiley on behalf of the Canadian Economics Association. Copyright restrictions may apply. doi: 10.1111/caje.12174

\section{Introduction}

In this paper, we ask whether being young in class, more precisely having one's birthday within the last six months prior to school entry, increases restless/inattentive behaviours of young children. Since "young in class" children can be almost one full year younger than some of their peers -- nearly a quarter of a lifetime for many children at school start age -- expectations for paying attention, sitting still, etc might be hard to achieve, leading them to "tune out" and/or "burst out" with more boisterous behaviours both at school and at home.

Increases in inattentive/hyperactive behaviour inadvertently generated by educational institutions are of economic and policy concern since there is evidence that higher levels of inattentive/hyperactive behaviour have negative implications for educational outcomes both for children with clinical levels of such behaviour (i.e., those with ADHD -- see Daley and Birchwood 2010; or Loe and Feldman 2007), and for those exhibiting some inattentive or hyperactive behaviours but who would be classified as well below clinical thresholds (Currie and Stabile 2006). Moreover, since the prevalence of inattentive/hyperactive behaviour has been growing worldwide ${ }^{1}$ and is more prevalent among boys than girls (e.g., Gershon 2002; Russell, Rodgers, Ukoumunne and Ford 2013), the issue has potential relevance to the growing concern both among economists (e.g., Bertrand and Pan 2011; Fortin, Oreopoulos and Philips 2013) and educators, more generally (Gurian 2009; Sax 2007) that boys are lagging girls academically. In Canada, for example, $60 \%$ of university graduates are now young women (Drolet 2011).

In this paper, we investigate three basic questions: 1) Are Canadian children in kindergarten through grade 3 who are young relative to their class-mates more likely to exhibit inattentive/hyperactive behaviours at home as reported by their parents, ${ }^{2}$ and if so, are there gender differences in the extent to which this is true? 2) Longitudinally, do children who exhibit higher levels of inattention/hyperactive behaviour at age $2 / 3$, before they enter public school have a particularly difficult time adjusting if they are young in class and is this particularly an issue for little boys?; 3) Do effects of being young at school persist into early adolescence?

In answering these questions, we make several contributions to the literature. First, we test the robustness of results to the use two different approaches to identifying the effects of being young in class on the inattentive/hyperactive behaviour of young Canadian school children. Specifically, we use both difference in difference (DD) estimation and the regression discontinuity (RD) techniques employed by other researchers on this topic. Each approach has strengths and weakness; since we employ both methods, we add to the literature the conclusion that being young in class increases inattentive/hyperactive behaviours regardless of the estimation approach employed. ${ }^{3}$

Second, given the longitudinal structure of the NLSCY we estimate the consequences of being young in class controlling for parent reports of inattentive/hyperactive behaviour at age 2/3, before the child enters school, using both OLS and sibling fixed effects methods. Thus, perhaps our most significant contribution to the literature is our estimate of how being young in class increases the inattentive/hyperactive behaviour of one sibling compared to another, when one is young in class while the other is not, controlling for differences in parental reports of their inattentive/hyperactive behaviour at age 2/3. The data set used by Elder (2010), for example, does not observe children until they are in kindergarten, so this was not studied previously. Similarly, sibling fixed effects models have not previously been used in this literature. ${ }^{4}$

\footnotetext{
${ }^{1}$ U.S. data (e.g., Akinbami, Liu, Pastor and Reuben 2011; CDC 2010; Child Trends 2012; Garfield, Dorsey, Zhu, Huskamp, Conti, Dusetzina, Higashi, Perrin, Kornfield and Alexander 2012; Getahun, Jacobsen, Fassett, Chen, Demissie and Rhodes 2013) and British data (Russell, Rodgers, Ukoumunne and Ford 2013) show increased prevalence of ADHD, even through the 2000's. Secular trends are hard to identify given changes in diagnostic practices, but increases in prevalence are apparent over the past 40 years (Perrin, Bloom and Gortmaker 2007). Current estimates suggest worldwide ADHD prevalence ranges between 4 and $10 \%$ (Faraone, Sergeant, Gillberg and Biederman 2003; FSGB; Skounti, Philalithis and Galanakis 2007; SPG; Spencer, Biederman and Mick 2007; SBM).

${ }^{2}$ Note that this is not the same thing as asking if the child has ever been diagnosed with ADHD. We are also interested in inattentive/hyperactive behaviours well below clinical thresholds.

${ }^{3}$ We also provide the first estimates using a nationally representative sample of Canadian children.

${ }^{4}$ Currie and Stabile (2006) also using the NLSCY, estimate sibling models. However, they are studying a different question (i.e., what are consequences of higher levels of the I/H score for educational outcomes).
} 
While we find no gender difference in the consequences of being young in class for equally inattentive/hyperactive boys and girls, we do find that children who are more inattentive/hyperactive before they start school, are most negatively affected by being young in class. Since pre-school boys have much higher levels of inattentive/hyperactive behaviour (even relative to their sisters), this result emphasizes the extent to which the negative consequences of being young in class on subsequent hyperactivity may contribute to the problems of boys at school. This effect may, indeed, be compounded if increases in inattentive/hyperactive behaviours lead to treatments with Ritalin which recent research (Currie and Stabile 2013) finds has very negative long-term effects of educational outcomes.

Finally, since we can follow some children from the ages of $2 / 3$ until the ages of $14 / 15$, we are able to estimate longerterm impacts of being young in class, controlling for pre-school behaviour. This is possible both for individual children and for sibling pairs. Again, other data sets employed in this literature do not provide the same richness of information, so this has not previously been possible. We find that children who are young in class are still more inattentive/hyperactive by age 10/11, the oldest group for whom we have comparable parental assessments of inattentive/hyperactivity; and, they are more likely to have repeated a grade and/or to have lower parent-assessed performance at school at 14/15.

The remainder of the paper is organized as follows. Section 2 outlines school start legislation in Canadian provinces. Section 3 discusses the NLSCY data. Section 4 outlines are basic research methodology and Section 5 presents results. Section 6 exploits the longitudinal structure of the NLSCY to control for inattentive/hyperactive behaviour at age 2/3 while section 7 tests the persistence of findings into early adolescence. Section 8 discusses the current relevance of this "young in class" issue, particularly with respect to the lagging educational performance of boys. Section 9 concludes.

\section{Kindergarten/Elementary School Legislation in Ten Provinces}

Provincial authority over education policy in Canada provides a significant level of variation across time and place in rules about when children start school. Kindergarten (grade primary in Nova Scotia) is available for five-year olds in all provinces, but what we principally exploit for our analyses is that the date by which the child must have turned five varies from September 1 to March 1. Table 1 shows the nine different school entry cut-off dates used during our study period.

Since a typical school year runs from September to the end of June in all provinces, children are admitted to school at one time each year. ${ }^{5}$ Whether they qualify for entry depends on their exact date of birth. Because of the single entry age cut-off, some children will be admitted to school a full year earlier than others. For example, if the cut-off date is December 31 in a calendar year when a child turns five, it means that children who are born on or before December 31 will start school when they are 4 years and 8 months and become the youngest student in the class. On the other hand, children who are born on January 1 will have to wait till next year to enter kindergarten, which means they actually start when they are 5 years and 8 months, and become the oldest student in the class.

With the exceptions of Alberta and Saskatchewan, school entry age eligibility in Canada is determined by the provincial Ministry of Education and is specified in provincial statutes that are usually contained in provincial Education Acts. Within the provinces of Alberta and Saskatchewan, school boards may set their own age requirements for entering school (see notes to Table 1). For the purpose of this study, we utilize information on school entry age cut-off in eight provinces and school boards/districts of Alberta and six school boards in Saskatchewan that can be identified by the Census Metropolitan Area (CMA) code available in the NLSCY. Data are directly compiled from provincial Education Acts and Department of Education or school board websites. We also use additional sources to help verify the compilation, including a survey on school start age across Canada by the PEI Department of Education, ${ }^{6}$ and publications by Statistics Canada that summarize school eligibility legislation.

As shown in Table 1, the most common cut-off date for school eligibility across provinces is December 31. During our study period, six provinces (i.e. British Columbia, Manitoba (1987-2000), Ontario (2001-2004), New Brunswick, Newfoundland and Labrador, six school districts in Saskatchewan and 4 school districts in Alberta) used this cut-off

\footnotetext{
${ }^{5}$ Staggered entry throughout the school year is another option used in the UK, Cornelissen, Dustmann and Trentini (2013) for example.

${ }^{6}$ 2003. http://www.ed.gov.nl.ca/edu/k12/kindergarten.html.
} 
This is an author-produced, peer-reviewed version of this article. The final, definitive version of this document can be found online at Canadian Journal of Economics. Published by Wiley on behalf of the Canadian Economics Association. Copyright restrictions may apply. doi: $10.1111 /$ caje.12174

date to determine eligibility for kindergarten. The second most common school-entry cut-off date is September 30, used in Quebec and Nova Scotia. Otherwise, start date varies widely: for example, Calgary uses September 1 while Edmonton uses March 1. Also, PEI and Manitoba have both made several changes in cut-off date during our study period.

Of note is the fact that kindergarten is only mandatory in Quebec. ${ }^{7}$ Compulsory schooling outside Quebec begins in grade one (see Oreopoulos 2005 and 2006). Nevertheless, as we will show, in all provinces nearly all families comply with the norms established through legislation and begin public school with kindergarten at the "appropriate" age.

\section{Data}

Statistics Canada's National Longitudinal Survey of Children and Youth (NSLCY) is a nationally representative dataset of Canadian children that tracks their development and well-being from birth to early adulthood, with data collection occurring at two year intervals. The first survey round took place in 1994/95 with a nationally representative sample of 22,831 children aged $0-11$. In addition to following the original longitudinal children, a new cohort aged 01 was added at each new cycle allowing the construction of a sizable repeated cross-sectional dataset. Most information for children under the age of 10 is reported by a parent, specifically the parent selected as the "person most knowledgeable" about the child (or, PMK - most typically the mother) during a personal interview in the home.

In the first section of the paper, we select a longitudinal sample of children who are currently between 5 and 8 years of age, ${ }^{8}$ who are attending public school or publically funded Catholic schools and for whom we can also observe province of residence when he/she was $4 / 5$ years old ${ }^{9}$ so that we can determine the relevant elementary school eligibility cut-off date. ${ }^{10}$ Our basic estimating sample excludes children who have moved inter-provincially between $4 / 5$ and $5 / 8$ on the grounds that this can change the meaning of being "relatively young in class." For example, a child moving from BC to NS could be up to 9 months younger than some of his/her classmates in NS rather than up to 6 months younger than classmates in BC (see Appendix Table 1). We have also estimated models which keep provincial movers; results are qualitatively unaffected (see Appendix Table 2). Since junior kindergarten is only available in some provinces, our basic sample excludes children currently attending junior kindergarten (though we later test the sensitivity of our results to having attended junior kindergarten). ${ }^{11}$

To maximize our sample size, we include any observations satisfying these conditions giving us 25,296 children. This means the same child can appear twice in our basic sample (e.g., when he/she was 5 and 7; or, when he/she was 6 and 8). An alternative sample in which each child is randomly selected once consists of 18,080 children. Appendix Table 3a and $3 b$ illustrates that our basic findings are consistent if we used the more restricted samples.

The measure of inattention/hyperactivity we use is based on parent reports. In all survey years, parents of young children were asked to assess how often, in the home setting, their child: ${ }^{12}$

\footnotetext{
${ }^{7}$ Ontario and Quebec offer two grades of kindergarten: junior kindergarten and senior kindergarten. Junior kindergarten, which is attended by four-year-olds, is optional in both provinces, but senior kindergarten is mandatory for five-year-olds in Quebec. Other provinces have only one year of kindergarten (called "primary" in Nova Scotia). Kindergarten usually runs on a half-day or every-other-day schedule, while starting in 2007 and 2010, Ontario and British Colombia introduced full-day Monday to Friday kindergarten. Starting in 2010, after our study period, kindergarten became compulsory in PEI. For more detailed description of kindergarten entry age in Canada, see Lefebvre, Merrigan and Verstraete (2009).

${ }^{8}$ For the purpose of sample selection, we use the NLSCY "effective age" since this determines the set of questions that will be asked about the child. Effective age is calculated as cycle year minus year of birth.

${ }^{9}$ Additionally, we exclude children who have moved inter-provincially after age 4/5.

10 The ability to match each child to the appropriate cut-off data is an advantage of the NLSCY not available to other authors. For example, Evans, Morrill and Parente (2010) do not have this information for any of the 3 data sets they employ.

11 We also exclude a small number of children who did not live in either one- or two-parent families (e.g., those in foster care or institutions). For Alberta and Saskatchewan, children living outside of the CMA's for which we know school start age rules are also excluded.

12 Specifically, pmk's are asked: "How often would you say [child's name] ..."
} 


\section{“Can’t sit still or is restless?” \\ "Is easily distracted, has trouble sticking to any activity?" \\ "Can’t concentrate, can’t pay attention for long?" \\ "Is impulsive, acts without thinking?" \\ "Has difficulty waiting for his turn in games or groups?" \\ "Can’t settle to anything for more than a few minutes?” \\ "Is inattentive?" 13}

For each behavior, the parent can choose: "never or not true" (=0); "sometimes or somewhat true" (=1); or, "often or very true" (=2). Responses are summed to construct a scale ranging in value from 0 to 14 , with a high score indicating the highest level of inattentive/hyperactive behaviour. The mean hyperactivity score for our sample is 4.1, though boys have higher scores than girls (4.6 compared to 3.6). Distributions of the hyperactivity scores for boys and girls are presented in Figure 1.

The NLSCY I/H score aligns nicely with the kinds of behaviours which, in their more extreme form, would be used to diagnose ADHD (Charach, Lin and To 2010; CLT). But, given past research suggesting that diagnosis of ADHD may be biased (e.g., Elder 2010; Evans 2010; Morrow, Garland, Wright, Maclure, Tayler and Dormuth 2012; MGWMTD) ${ }^{14}$ we prefer to work with a score describing the full range of inattentive/hyperactive behaviours - from none at all to clinical ADHD.

\section{Basic Research Methods}

To increase confidence in the robustness of our findings, we exploit two sources of variation to identify the effects of relative age on parent-reported inattentive/hyperactive behavior of Canadian children. ${ }^{15}$ First, across provinces and time ${ }^{16}$ we exploit differences in school start age policies which mean some children of exactly the same age (in months) are relatively young in class in one province but not another (difference in difference design - see Appendix Table 4). Second, within province, we exploit the randomness in exact date of birth for children born on either side of the school entry age cut-off and compare outcomes of otherwise similar children who received distinct treatment due to the enrolment eligibility legislation (regression discontinuity design). Each method has advantages and disadvantages.

The RD estimates compare children living in the same province who are born just before the school start cut-off who are thus the youngest members of their class with children who are born just after the cut-off and are the oldest members of their class. Since comparisons are being made within province, we can control potential curriculum and/or other provincial policy differences as well as potential local cultural differences in terms of parent/teacher expectations of young children. However, with the RD approach, the children being compared are in different grades and sample sizes are relatively small.

\footnotetext{
${ }^{13}$ Earlier cycles also contained an additional question (“fidgets”); we re-constructed the hyperactivity score to obtain cross-cycle consistently. See Appendix Table 11 for a comparison of these questions with ones used for the diagnostic of ADHD.

${ }^{14}$ Recent research (e.g., Elder 2010; Evans 2010; MGWMTD 2012) has found that children who are young within grade at school are more likely to be diagnosed with Attention Deficit Hyperactivity Disorder (ADHD). ${ }^{14}$ Using U.S. data., Elder, for example, finds that $8.4 \%$ of children born in the month prior to the state cut-off for kindergarten eligibility are diagnosed with ADHD compared to $5.1 \%$ for those born in the month after. Morrow, Garland, Wright, Maclure, Tayler and Dormuth (2012) report similar findings for the Canadian province of British Columbia.

${ }^{15}$ A related body of literature studies the implications of being absolutely younger when starting school (rather than being young relative to classmates). See for example, Black, Devereux and Salvanes (2011) or Cornelissen, Dustmann and Trentini (2013).

${ }^{16}$ However, the number of changes across time in school start age policies is more limited than the differences across provinces, thus, we rely more heavily on the cross-province policy variation.
} 
The DD estimates compare children of exactly the same age who are "young in class" in one province/time period but not young in another province/year as a result of provincial and/or year differences in school start dates. We are able to use larger samples for the difference in differences estimates and to estimate sibling fixed effects DD models to control for family-level unobservables (e.g., the priority parents place on education).

We do not study teacher reports since there are problems with these data in the NLSCY. Specifically, teacher response rates were only $48 \%$ even in the first cycle of the NLSCY in 1994; they were eliminated entirely after wave three (CLT 2010). Moreover, earlier research (Elder 2010) finds that teacher perceptions of a child's behaviour may be particularly likely to be systematically correlated with a child's age relative age to classmates and thus predictive of ADHD diagnosis while parental reports of child behaviour are not predictive of ADHD diagnosis.

Given these findings and the arguments of Currie and Stabile (2006) that a behavioural measure is better than a measure of diagnosis (given the biases noted above), we prefer to study the implications of being young in class on the full range of $\mathrm{I} / \mathrm{H}$ behaviour (see p. 9 and footnote 12). That is, we want to know if children who are young in class are reported to be "more restless" or "less attentive" even if their behaviour is not likely to lead to a diagnosis of ADHD.

\subsection{Difference in Difference Design}

Differences across the ten provinces in the cut-off dates for school entry as well as changes in cut-off dates during our study period for some provinces provide sufficient variation to allow us to compare children of exactly the same age in provinces with different cut-offs, so that in one province, the child is "young in class" while in the other, he/she is "old in class." We first estimate a basic OLS model:

$$
\begin{aligned}
& \text { I/H } \mathrm{H}_{\mathrm{i}}=\alpha+\tau \text { Young6mosip }+\beta_{1} \text { Ageinmonths }_{\mathrm{i}}+\beta_{2} \text { Agesq }_{\mathrm{i}}+\beta_{3} \text { Agecubed }_{\mathrm{i}}+ \\
& \beta_{4} \text { BirthQuarter }_{\mathrm{i}}+\beta_{5} \text { Cycle }_{\mathrm{i}}+\lambda \mathrm{X}_{\mathrm{i}}+\varepsilon_{\mathrm{i}}
\end{aligned}
$$

where $\mathrm{I} / \mathrm{H}_{\mathrm{i}}$ is the inattentive/hyperactivity score (based on parent report) for child $\mathrm{i}$; Young6mosip is a dummy variable indicating that the child's birth date puts him/her in the younger half of his/her classgiven school-entry legislation in that year and province; Ageinmonths ${ }_{i}$ is the child's age in months at the time of the survey; ${ }^{17}$ BirthQuarter $_{i}$ indicates season in which the child was born; Cycle ${ }_{i}$ refers to the NLSCY cycle from which the observation is drawn (beginning with Cycle 1 collected in 1994 through Cycle 8 collected in 2008); $\mathrm{X}_{\mathrm{i}}$ includes an indicator that the child is first-born, child gender (in pooled boy/girl models), parental education, log family equivalent income, ${ }^{18}$ family structure and parent immigrant status.

We include quarter of birth to control for the fact that children born in different seasons are often found to have different outcomes, with those born during the winter having the worst outcomes (e.g., Buckles and Hungerman 2013) and these seasonal effects may confound our findings regarding young in class, especially since several provinces place the school cut-off at December 31.

We estimate the DD model for the combined sample of boys and girls as well as separately for boys and girls. Since we require the child to be present in the data both at school entry and at age $5 / 8$, longitudinal weights are used for all estimates; robust rstandard errors are clustered by province.

We next estimate a sibling fixed effects version of the DD model:

$$
\begin{aligned}
& \mathrm{I} / \mathrm{H}_{\mathrm{ij}}=\alpha+\tau \text { Young6mos }_{\mathrm{ijp}}+\beta_{1} \text { Ageinmonths }_{\mathrm{ij}}+\beta_{2} \text { Agesq }_{\mathrm{ij}}+\beta_{3} \text { Cycle }_{\mathrm{ij}} \\
& \lambda \mathrm{X}_{\mathrm{ij}}+\rho_{\mathrm{j}}+\varepsilon_{\mathrm{ij}}
\end{aligned}
$$

\footnotetext{
${ }^{17}$ This is important, since inattentive/hyperactive behaviours change, generally diminishing with the child's age (e.g., SBM 2007).

${ }^{18}$ Family incomes are in real 2006 Canadian dollars, using CPI with 2001 basket content. "Equivalent" income adjusts dollar income to reflect differences in needs of families of different size. We use the Luxembourg Income Study equivalence scale (square root of family size) to make this adjustment.
} 
This is an author-produced, peer-reviewed version of this article. The final, definitive version of this document can be found online at Canadian Journal of Economics. Published by Wiley on behalf of the Canadian Economics Association. Copyright restrictions may apply. doi: 10.1111/caje.12174

where $X_{\mathrm{ij}}$ now includes only child gender since other parent/family characteristics will be the same for both children; $\rho_{\mathrm{j}}$ is a family fixed effect. This specification should control for fixed, unobservable differences across parents (e.g., very highly motivated that children should excel at school).

\subsection{Regression Discontinuity Design}

Following Elder (2010), our second approach to estimate the effect of a child being relatively young in his/her class at school on parent reports of child hyperactivity is to compare children living in the same province who were born shortly before compared to shortly after the relevant school cut-off date. The RD approach has also been used to study a implications of being relatively young in class for a variety of child outcomes (e.g., Dhuey and Lipscomb 2010; Dobkin and Ferreira 2010) though no studies of which we are aware exploit the variation that exists in school-entry policies across Canada (though see Bedard and Dhuey 2006; MGWMTD 2012; Smith 2007 for studies using data within the province of British Columbia).

Intuitively, the idea of the RD strategy is that it is hard to think of any plausible reason why, for example, a Nova Scotian child born in September would be more hyperactive than a Nova Scotian child born in October of the same year except that the September child would be the youngest in his or her class while the October child would be among the oldest. But, Figure 2 shows that, in fact, Canadian children born just prior to the school cut-off date have higher levels of inattention/hyperactivity than those born just after. This is evident both in the pooled boy/girl sample and in separate estimates for boys and for girls (see Figure 3).

More formally, we estimate the following RD model:

$$
\mathrm{I} / \mathrm{H}_{\mathrm{i}}=\alpha+\tau \text { Young }_{\mathrm{i}}+\gamma \mathrm{f}\left(\mathrm{bd}_{\left.\mathrm{i}-\mathrm{C}_{\mathrm{i}}\right)}\right)+\beta_{1} \text { Province }_{\mathrm{i}}+\beta_{2} \text { Cycle }_{\mathrm{i}}+\beta_{3} \text { Grade }_{\mathrm{i}}+\lambda \mathrm{X}_{\mathrm{i}}+\varepsilon_{\mathrm{i}}
$$

where Young i is now a dummy variable indicating that the child has a birth-date in the period immediately prior to the school-entry cut-off; ${ }^{19} \mathrm{f}\left(\mathrm{bd}_{\mathrm{i}}-\mathrm{C}_{\mathrm{i}}\right)$ is a function of the number of days between the child's exact birthdate, bd, and his or her relevant school-entry cut-off date; ${ }^{20}$ Province is the child's province of residence; Grade ${ }_{i}$ refers to the child's current grade at school (in a cubic specification).; $X_{\mathrm{i}}$ includes child gender (in pooled boy/girl models), parental education, log family equivalent income, family structure, and parent immigrant status. We control for school grade in a cubic specification. Longitudinal weights are employed for all analyses; standard errors for the RD estimates are clustered at birth dates.

\section{Basic Estimation Results}

\subsection{Difference in Difference Results}

Difference-in-difference (DD) results are reported in Table 2. For both boys and girls, we find that children who are young in class have more parent-reported symptoms of inattention/hyperactivity than their peers in other provinces/time periods who are the same age in months, but who are positioned differently relatively to their classroom peers as a result of differences across place/time in school start cut-offs. While boys have significantly higher inattentive/hyperactive scores than girls (about 1 point relative to the over-all mean of about 4 points on a scale of 0 to 14), the size of the "young in class" effect is fairly similar for boys and girls ( 0.17 of a standard deviation for boys; 0.12 of a standard deviation for girls). ${ }^{21}$ Formal statistical tests reject the hypothesis of a significant difference in the size of the "young" effect for girls and boys (i.e., the interaction of "boy" and "young" is never statistically significant in pooled models). Relative to other key covariates, the size of effect for being young in class is roughly $60 \%$ as large as having a parent with a university level education, for example, though in the opposite direction. The young in class effect is much the same size as the lone-mother association for girls (about $80 \%$ as large for boys). ${ }^{22}$

\footnotetext{
${ }^{19}$ We have used windows around the school cut-off day ranging from one month before and one month after to six months before and six months after.

${ }^{20}$ We have tried specifying $\mathrm{f}\left(\mathrm{bd}_{\mathrm{i}}-\mathrm{c}\right)$ as a linear, quadratic and cubic function. See Appendix Table 5.

${ }^{21}$ Evans, Morrill and Parente (2010) also found no significant difference for boys compared to girls.

${ }^{22}$ Bertrand and Pan (2011) also find that boys have a harder time in lone-mother families.
} 
Notice that the quarter of birth variables are not significant in any case, which is, perhaps, surprising given other work on this topic. Recent findings of Buckles and Hungerman (2013) indicate that quarter of birth differences in child outcomes in the U.S. are in fact due to differences in maternal characteristics, with the driving factor being that older, more educated mothers are more likely to time their births to coincide with the summer months. For comparison with Buckles and Hungerman, Appendix Table 5 illustrates the results of simple OLS regressions of mother characteristics on quarter of birth and cycle. In contrast with the U.S. evidence, we do not find that mothers with children born in the winter are of lower socioeconomic status. This may reflect an important institutional difference between Canada and the U.S.; namely, the fact that at least six months of maternity leave was available to mothers in Canada during our study period whereas no paid leave was available to mothers in the U.S. (see Phipps 2010). If they have six months off, the more well-educated Canadian mothers will not need such precision timing in order to enjoy leave during the summer months.

The final three columns of Table 2 report sibling fixed effects models for all children with a sibling in the data who also satisfies all sample selection criteria. Though sample sizes are much smaller (1993 sibling pairs), results remain consistent. That is, if one sibling is young in class while the other is not, the "young in class" sibling is more inattentive/hyperactive, controlling for age, birth order, quarter of birth and cycle.

Since there may be concern that parents may have a bias toward thinking that boys are more boisterous that girls, we also estimate the above sibling fixed models for brother/brother and sister/sister samples and find that being young in class causes an increase in inattentive/hyperactive behaviour for girls who are young in class compared to their sisters who are not; boys who are young in class exhibit more inattentive/hyperactive behaviour than their brothers who are not. In fact, the coefficient size for the "young" variable is particularly large when there are no gender differences between siblings.

Table 3 presents potentially policy-relevant results. Specifically, we re-estimate the basic DD model (Equation 1, above) separately for children who family equivalent income is above versus below the mean. As well, we estimate a version with all children plus a control for "less than mean" and an interaction between "less than mean" and "young." Results show that the effect size is smaller for children from lower-than-mean-income families, though still important for children from higher-than-mean-income families.

\subsection{Regression Discontinuity Results}

$\mathrm{RD}$ results for the pooled boy/girl sample are presented in Table 4 which reports only the estimated coefficient for "boy" and for the "young" variable (results for other covariates are similar to those reported for the DD models). We report results for window lengths of two and three months before/after the school cut-off date. Again, we find that children who are relatively young in class are reported by their parents to exhibit more inattentive/hyperactive in the home setting. Children who are relatively young in class have scores that are about 0.5 points higher than their peers on the "other side of the window;" similar in magnitude to those obtained using DD methods.

Again, while boys have significantly higher inattentive/hyperactive scores than girls (about 1 point), we never find a statistically different impact of being young in class for boys than for girls. In the estimates reported here, we include all covariates and use a linear specification for the distance from cut-off function, $\mathrm{f}\left(\mathrm{bd}_{\mathrm{i}}-\mathrm{C}_{\mathrm{i}}\right)$. We have also used quadratic and cubic specifications for the running variable; these are reported in Appendix Table 7. The basic conclusion that children who are relatively young in class exhibit more inattentive/hyperactive behaviour than their relatively older peers holds.

In order for our interpretation that higher levels of inattentive/hyperactive behaviours are caused by being young relative to class-mates, we do not want it to be the case that other potential reasons for hyperactivity "jump" near the school start-date cut-off. One very nice feature of the RD strategy is that it is easily possible to test for discontinuities in observable variables by estimating a set of regressions of the form of equation (2) for each of the covariates in our data set (Dobkin and Ferreira 2009 and Lee and Lemieux 2010). Appendix Table 7 reports results for both two and three-month windows and find no evidence of discontinuities around the cut-off for any of the covariates except, as we would expect, that grade is statistically significant (and positive). 
This is an author-produced, peer-reviewed version of this article. The final, definitive version of this document can be found online at Canadian Journal of Economics. Published by Wiley on behalf of the Canadian Economics Association. Copyright restrictions may apply. doi: $10.1111 /$ caje.12174

Our finding of an increase in parent-reported inattentive/hyperactive behaviours of Canadian children who are "young in class" thus appears to be different from Elder's conclusion (2010) that while teacher reports of "young in class" child behaviour are predictive of ADHD diagnosis, parent reports are not. However, the two papers are not asking the same question.

Elder's goal is to determine if diagnosis (and thus treatment) of ADHD is affected by relative age comparisons in teacher/parent assessments of ADHD-like behaviours whereas we are interested in whether children who are young in class are more restless or inattentive than other children at levels far below ADHD diagnosis since that can lead to poorer schooling outcomes (Currie and Stabil, 2006). In fact, Elder finds, as we do, that both teachers and parents report "young in class" children to be less "socially and cognitively developed;" the discrepancy in findings only appears when he uses reports of behaviour to predict ADHD diagnosis -- in this case, only teachers' reports are predictive. Elder does not directly use behavioural scores as dependent variables in his RD estimates given his focus on relative age effects on diagnosis.

Indeed, as Elder points out (p. 645), the behavioural scales available to him would not be well-suited for a direct study of the full range of inattentive/hyperactive behaviour which is our focus. That is, some of the behavioural scales available to him are not intended to measure ADHD-type behaviours; for example, there is a measure of emotion and one for interpersonal relations. We are fortunate to have available a behavioural scale for which all components match criteria by which ADHD is assessed (see DSM-IV criteria for ADHD, American Psychiatric Association, 2000). See Appendix Table 11 where we indicate with a * criteria overlapping with DSM-IV criteria. ${ }^{23}$

\section{$\underline{5.3 \text { Robustness Checks }}$}

\subsubsection{Choice of Sample}

Table 5 presents a series of robustness checks for our DD models, our focus for the rest of the paper. (Appendix Tables $8 \mathrm{a}$ and $8 \mathrm{~b}$ report the same DD robustness checks for boys and girls separately while Table 8 reports these robustness checks for 3-month RD models.) Currie and Stabile (2006) have noted that there are strong negative associations between inattentive/hyperactive behaviour and human capital acquisition at well below "clinical" levels of these behaviours (i.e., for children who are inattentive or restless but who certainly do not have ADHD). ${ }^{24}$ Thus, a first test for robustness compares results for children with less than mean $\mathrm{I} / \mathrm{H}$ scores with those for children with above mean scores. ${ }^{25}$ An important point, pursued later in the paper, is that the "young in class" effects are not apparent for children with less than the mean I/H score. These "lower half" children have a mean I/H score of 2 on the 0 to 14 scale and 55 $\%$ are girls. Thus, not only does the "young" effect disappear, but the magnitude of the "boy" coefficient falls from 1.054 to 0.251 .

It is also possible that some children born just after the school entry age cut-off, yet who were perceived as "ready" to start school were sent to private schools that might be more flexible with respect to parental preferences. Again, although this would suggest that we under-estimate the true effect of birth date on inattentive hyperactive behaviour of children, if parents are more likely to start particularly able children early, we repeat our analyses for a sample that includes all children in the NLSCY regardless of their schooling status (i.e., home-schooled or not) or type of school

${ }^{23}$ Other more minor differences between Elder's work and ours are: 1) he uses behavioural scores reported in late fall 1998 for children who started K in fall 1998; thus they are younger/nearer to school entry than our sample of children (who can be anywhere from 5 to 8 and can have been surveyed at any time during the year except the summer months); 2) school entry cut-offs in the U.S. states are generally in August/September/October (Sept 1 is most common); only 3 states with Dec 31) so U.S. children are, on average, a few months older when they start school.

${ }^{24}$ Attention-Deficit/Hyperactivity Disorder (ADHD) is among the most commonly diagnosed behavioural disorders for children in many countries (Elder 2010; FSGB 2003; SPG 2007). ADHD is a developmental, neurobiological condition defined by the presence of severe and pervasive symptoms of inattention, hyperactivity and impulsivity which must be exhibited over a period of at least 6 months, before the age of 7 and in at least two contexts such as home and school (Daley and Birchwood 2010; Loe and Feldman 2007).

${ }^{25}$ Perhaps surprisingly, given the availability of public health insurance in Canada, rates of treatment with Ritalin seems to be lower in Canada than in the U.S. (e.g., Currie and Stabile (2006) estimated that $1.4 \%$ of Canadian children aged 4 to 11 in 1994 took Ritalin, compared to $3.3 \%$ in of the same age and in the same year in the U.S. In our sample, $2.8 \%$ of boys; $0.8 \%$ of girls, so results are not affected if we exclude children on Ritalin. 
This is an author-produced, peer-reviewed version of this article. The final, definitive version of this document can be found online at Canadian Journal of Economics. Published by Wiley on behalf of the Canadian Economics Association. Copyright restrictions may apply. doi: 10.1111/caje.12174

attended (public or private). Since less than $4 \%$ of children in grades K through 4 attend private school in Canada, results are also robust to adding children who are home-schooled or attending private schools back into the sample (see Table 5).

A further issue is that some regions offer public junior kindergarten and some do not and the availability of daycare varies across the country. ${ }^{26}$ Since having attended junior kindergarten or structured daycare may later influence the child's behaviour in kindergarten or grade one, we control for whether the child attended a structured daycare or a junior kindergarten when he/she was 3/4. To do this, it is necessary to further limit our sample to children observed at age 3 or 4 and with answers to questions about attendance in junior kindergarten or formal daycare at that time. Again, our main causal findings about increased inattentive/hyperactive behaviour for children who are relatively young at school are unaffected by the inclusion of this control. ${ }^{27}$

\subsubsection{Compliance with Legislation}

Since our analysis defines children as young in class by comparing their birth date with the legislated school start date for their province/time period, a concern might be that parents do not always comply with the legislation. For example, if some parents are aware of the literature on being "young in class," they may choose to hold their children back in order to provide an advantage relative to peers (academic "redshirting"). This seems particularly likely if the child is perceived as "not ready" for school. If this is so, then we would have more "less able" children in the "old" group, and we would underestimate the implications of being "young." However, Appendix Table 10 indicates that, in Canada, only a very small number of children are not in compliance with the school entry regulations in their year/province (at most $3 \%$ ). Not surprisingly, then, we see almost no change in estimates if these children are excluded from our sample. ${ }^{28}$

\subsubsection{Strategic Timing of Births}

Another concern could be that some parents, aware of the "young in class" literature, attempt to time the month of their child's birth to ensure that he/she is old in class. Bedard and Dhuey (2006) find no evidence of such behavior in their study of 20 countries, nor do we find a jump in birth frequency just after the school entry threshold in our data (see Figure 5, that uses pooled cycles of data for provinces without a change in school entry date). Moreover, the sibling fixed effects models reported in Table 2 should control for an unobservable such as parental desire to advantageously time their children's births.

\section{Is Being Young at School Harder for Children with Greater Inattention/Hyperactivity Prior to School Entry?}

The consensus in the medical literature appears to be that while ADHD diagnosis most often occurs during the elementary school years, symptoms of inattentive/hyperactive behaviour are typically already evident during the preschool years (Loe, Balestrino, Phelps, Kurs-Lasky, Chaves-Gnecco, Diego, Jack and Feldman 2008). And, the robustness checks discussed in the previous section suggest that children with the most inattentive/hyperactive behaviour are most affected by being young in class. In this section, we make further use of the longitudinal nature of the NLSCY to ask whether increases in inattentive/hyperactive behaviour associated with being young in class are larger for children who exhibit more inattentive/hyperactive behaviours before they arrive at school entry age? That is, do children who have troubles sitting still or paying attention find it harder to cope in a classroom when they are

\footnotetext{
${ }^{26}$ See, for example, Lefebvre and Merrigan (2008) or Lefebvre, Merrigan and Verstraete (2009).

${ }^{27}$ While there is no association between having attended junior kindergarten at 3/4 and current inattentive/hyperactive score, we do find a correlation between having attended structured daycare at 3/4 and higher inattentive/hyperactive scores at 5/8. This is consistent with the findings of Baker, Gruber and Milligan (2008).

${ }^{28}$ Indeed, these results cannot be released from the Research Data Centre in order to avoid possible residual disclosure, given the very small numbers of children involved. This contrasts with U.S. findings of growing numbers of “redshirted” children (e.g., Deming and Dynarski, 2008; Evans, Morrill and Parente 2010).
} 
This is an author-produced, peer-reviewed version of this article. The final, definitive version of this document can be found online at Canadian Journal of Economics. Published by Wiley on behalf of the Canadian Economics Association. Copyright restrictions may apply. doi: 10.1111/caje.12174

among the youngest members of their class? ${ }^{29}$ To the best of our knowledge, this question has not previously been studied in the literature, and may be particularly important for a gender comparison, given that pre-school boys are more inattentive/hyperactive than girls (see Figure 4).

Restricting the sample to children for whom we have parent reports of hyperactivity both at ages 2/3 and at ages 4 through 9, we estimate the following difference-in-difference specification:

$$
\mathrm{I} / \mathrm{H}_{\mathrm{i}}=\alpha+\tau_{1} \text { Young6mos }_{\mathrm{ip}}+\tau_{2} \mathrm{I} / \mathrm{H} 2 / 3_{\mathrm{i}}+\beta_{1} \text { Ageinmonths }_{\mathrm{i}}+\beta_{2} \text { Cycle }_{\mathrm{i}}+\lambda \mathrm{X}_{\mathrm{i}}+\varepsilon_{\mathrm{i}}
$$

where $\mathrm{I} / \mathrm{H} 2 / 3_{\mathrm{i}}$ is the child's inattentive/hyperactive score at age 2 or 3 and other explanatory variables are as described for the difference-in-difference model (1) above. We estimate both the OLS model described above as well as a sibling fixed effects version.

Results for these models are reported in Tables 6. Key findings are that: 1) there is strong persistence in reported inattentive/hyperactive behaviour which is unaffected by adding the "young" variable to the model; 2) being young in class nevertheless increases parent reports of inattention/hyperactivity, even controlling for scores reported prior to school entry, in both OLS and sibling fixed effects models. This is one of our strongest findings - children who are young in class, compared to their sibling who is not, exhibit more inattentive/hyperactive behaviours, even controlling for differences in their I/H scores at age 2/3 (as well as differences in gender, age in months at survey, birth order and quarter of birth).

Finally, to test whether children who already exhibit many inattentive/hyperactive behaviours during their pre-school years are most strongly affected by being young in class, we estimate a version of (4) above in which we model I/H using dummies to indicate quartile of the pre-school I/H distribution plus interactions between I/H2/3 quartile and the "young" variable.

The results are reported in column 4 of Table 6. We find, as expected, that children who are the most inattentive/hyperactive pre-schoolers are the ones who have the most difficulty being young in class. Since boys comprise $57 \%$ of the toddlers in the highest quartile of the hyperactivity distribution, in this sense, being "young in class" is more of a boys' than a girls' issue.

\section{$\underline{\text { 6.1. Falsification Test }}$}

The sample of children observed since the age of $2 / 3$, provides an opportunity to conduct an interesting falsification test. Specifically, we can regress $\mathrm{I} / \mathrm{H}$ score at age $2 / 3$ on an indicator that this child will be young in class when he/she reaches school age (as well as the full set of controls used in earlier DD models). Results are reported in Table 7 where we find that the "will be young in class" variable does not predict reported inattentive/hyperactive behaviours at age $2 / 3$.

\section{Do the Effects of Being Young in Class Persist into Early Adolescence?}

There is some dispute in the literature about how long-lasting are the effects of being young in class. Bedard and Dhuey (2008) present evidence for a variety of countries (and the Canadian province of BC) that relative school start age effects persist into the adult years; Smith (2007), using the same BC data set, also finds evidence of effects persisting into the high school years. On the other hand, Bertrand and Pan (2011) argue, using U.S. data, that effects dissipate; Dobkin and Ferreira (2010), again in the U.S. context, argue that there are no long-term implications for adult labour market outcomes since younger children, on the one hand, have poorer academic outcomes during their school years, but, on the other hand, are more likely to pursue further education.

\footnotetext{
${ }^{29}$ MacPhee (2012) finds that pre-school children who are more hyperactive are less likely to be read to than their
} siblings. 
This is an author-produced, peer-reviewed version of this article. The final, definitive version of this document can be found online at Canadian Journal of Economics. Published by Wiley on behalf of the Canadian Economics Association. Copyright restrictions may apply. doi: $10.1111 /$ caje.12174

Using the parent-reported inattentive/hyperactive score for children aged 10 and 11, we re-estimate the basic and the sibling fixed effects DD models as well as the models that control for hyperactivity observed at age 2/3, again using both OLS and sibling fixed effects. We choose children aged 10 and 11 , since this coincides with current average age of puberty onset (Toppari and Juul, 2010) and, pragmatically, is the oldest age for which we have parent reports of inattentive/hyperactive behaviour.

Results are summarized in Table 8 (OLS) and Table 9 (Sibling FE) and are, in all cases, consistent in both size and significance with those reported earlier. That is, at age 10/11, we continue to find that children who are "young in class" exhibit more inattentive/hyperactive behaviours than other children, controlling parent-reported inattentive/hyperactive behaviours at age 2/3, and in both OLS and sibling FE DD models.

Although the NLSCY does not provide parent reports of I/H behaviours beyond the age of 10/11, parents of 14/15 year old youth are asked if their child has ever repeated a grade at school and they are asked to assess the child's overall performance at school: "Based on your knowledge of his schoolwork, including report cards," how is [your child] doing overall?” Responses possibilities are: Very well, well, average, poorly, very poorly. For our analyses, we code from 1 to 5 , with 5 corresponding with "very well."

Table 8 reports DD results using over-all success at school and grade repetition as dependent variables. We find that children who were young in class at school entry are reported by their parents to be less successful at school at age 14/15 (estimate size is 7 to $9 \%$ of a standard deviation). "Young in class" children are also more likely to have repeated a grade at school by age 14/15 (estimate size is 13 to $16 \%$ of a standard deviation). Table 9 repeats these analyses using sibling fixed effects DD models. Although sample size becomes quite small (only 478 sibling pairs that we can observe from age 2/3 until age 14/15), the same patterns are apparent.

\section{Discussion}

We argue that this issue is of greater concern now than was the case in the past (when there were of course also "young in class" children). ${ }^{30}$ First, while children are only required by law to be in school by the age of six in most jurisdictions, as we have demonstrated, the overwhelming majority of Canadian children actually begin formal education in the public school system at age $4 / 5$. They also spend more hours in class at an earlier age than was previously the case (e.g., full day kindergarten versus half day kindergarten). A simple point is that being one year younger than a classmate is likely to represent a larger developmental gap at a younger age. Attempting to keep up with classmates doing tasks such as forming letters and numbers is likely to be particularly frustrating.

Second, young children are known to be more inattentive/hyperactive than was true even 10 or 15 years ago (Akinbami, Liu, Pastor and Reuben 2011; Brault, Marie-Christine and Lacourse, Eric 2012; CDC 2010; Child Trends 2011; Garfield, Dorsey, Zhu, Huskamp, Conti, Dusetzina, Higashi, Perrin, Kornfield and Alexander 2012). ${ }^{31}$ Given our finding that children who start school with the highest levels of $\mathrm{I} / \mathrm{H}$ behaviour are most negatively affected by being young in class, this trend could mean that effect size is larger now than in the past. Moreover, since studies of recent prevalence trends show the same gender gap as previously albeit at higher levels for both boys and girls, the problem may plausibly contribute to the "boys" problem' in Canadian schools.

Finally, there is a possibility that increases in inattentive/hyperactive behaviour inadvertently caused by school entry policies may lead to diagnosis of ADHD and treatment using Ritalin. This is most likely for children starting school with high inattentive/hyperactive scores (most likely boys) for whom being young in class leads to a further increase

\footnotetext{
${ }^{30}$ The highly feminized environment of schools in the early years might also be relevant (e.g., female teachers may be less sympathetic to boisterous behavior). Certainly, it is the more "hyperactive" behavior that teachers find most disruptive in the classroom (Abikoff, Jensen, Arnold, Hoza, Hechtman, Pollack, Martin and Wigal 2002). On the other hand, teachers of the early grades at school have been primarily female for many years, so this particular factor may have changed less than some others.

${ }^{31}$ Explanations for increased I/H behaviour include: 1) increased time watching television, playing video games and/or on a computer (e.g., Chan and Rabinowitz, 2006; Lingineni, Biswas, Ahmad, Jackson, Bae and Singh 2012); 2) increased obesity (e.g., Cortese, Angriman, Maffeis, Isnard, Konofal, Lecendreux, Purper-Ouakil, Vincenzi, Bernardina and Mouren 2008; Waring and Lapane, 2008); 3) even, less time in the sun (Arns, van der Heijden, Arnold and Kenemans 2013).
} 
This is an author-produced, peer-reviewed version of this article. The final, definitive version of this document can be found online at Canadian Journal of Economics. Published by Wiley on behalf of the Canadian Economics Association. Copyright restrictions may apply. doi: 10.1111/caje.12174

in I/H score of about one quarter of a standard deviation. Since recent research (Currie and Stabile 2013) finds negative effects on educational outcomes for Canadian boys (but not girls) who have been treated with Ritalin, there is additional cause for both economists and policy makers to be concerned about school entry policies.

Our results provide some potentially useful ideas for policy development in this area. First, we find that children from lower-income families are particularly susceptible, as are children already exhibiting some inattentive/hyperactive behaviours as pre-schoolers. This may help to focus resources where they will be most effective.

In terms of what to do, one possibility would be to stagger school entry across the first year as is the case in England (Cornelissen, Dustmann and Trentini 2013) where children may enter in September, January or April. In this case, children in the entering cohort would be much close to the same age (i.e., all birth dates falling within the same 4 months). Of course, this may cause logistical problems if entering cohorts are simply added to existing classes. Also, Cornelissen, Dustmann and Trentini (2013) find that children who have been in school for fewer months have poorer outcomes, both cognitive and behavioural, than those with more months of "exposure" to the classroom.

Alternatively/additionally, a growing body of research suggests that vigorous aerobic exercise may be a helpful longerterm treatment option for children with ADHD (Chang, Liu, Yu and Lee 2012; Medina, Netto, Muszkat, Medina, Botter, Orbetelli, Scaramuzza, Sinnes, Vilela and Miranda 2010; Tantillo, Kesick, Hynd and Dishman 2002), even perhaps altering the development trajectory of the condition (e.g., Archer and Kostrzewa 2012; Halperin and Healey 2011). It seems possible, therefore, that increasing time devoted to exercise for young children could be beneficial to many "fidgety" children (and might also help reduce child obesity). Again, given our results, this should be a priority for young boys.

\section{Conclusions}

We find that being young in class increases parent reports of inattentive/hyperactive behaviour for 5 to 8 year-old Canadian children. Importantly, we find that being young in class increases inattentive/hyperactive behaviour, both for children at clinical levels (i.e., those with ADHD) and for those whose behaviour is well below clinical thresholds. Using nationally representative data (the Statistics Canada National Longitudinal Survey of Children and Youth, or NLSCY), we employ both difference in difference and regression discontinuity techniques, exploiting variation across time and place in school entry laws. The longitudinal structure of the NLSCY also allows us to control for parent reports of child inattentive/hyperactive behaviour at ages $2 / 3$, before the children start school. We find that being young in class exacerbates an underlying tendency toward inattentive/hyperactive behaviours, perhaps even pushing some children to clinical levels. All results hold in both OLS and sibling fixed effects models. Although our principal focus is on children who are aged 5 to 8 , we also find that the effects of being "young in class" on inattentive/hyperactive behaviours persist to age 10/11; and we find negative effects on grade repetition and over-all school performance at $14 / 15$.

Our interest in the causal implications of being young in class for observed inattentive/hyperactive behaviour of young school aged children grew from our interest in the lagging academic outcomes of boys, a line of thought not pursued in earlier U.S. studies. Since boys have much higher levels of inattentive/hyperactive behaviour prior to starting school and since children starting school with higher levels of inattentive/hyperactive behaviour are the ones particularly affected, in this sense, the problem we identify is more of a "boy"s' than a "girl"s' issue.

\section{References}

Abikoff, H. B., P.S. Jensen, L.E. Arnold, B. Hoza, L. Hechtman, S. Pollack, D. Martin and T. Wigal (2002) "Observed Classroom Behavior of Children with ADHD: Relationship to Gender and Comorbidity." Journal of abnormal child psychology 30(4), 349-59

Akinbami, L.J., X Liu, P.N. Pastor, C.A. Reuben (2011) "Attention deficit hyperactivity disorder among children aged 5-17 years in the United States, 1998-2009." U.S. Department of Health and Human Services. Centers for Disease Control and Prevention. National Center for Health Statistics Data Brief. 70, 1-8.

Almond, D., and J. Currie (2011) "Killing Me Softly: The Fetal Origins Hypothesis.” Journal of Economic Perspective, 25(3), 153-72

Archer, T, and R.M. Kostrzewa (2012) "Physical Exercise Alleviates ADHD Symptoms: Regional Deficits and Development Trajectory.” Neurotoxicity Research, 21(2), 195-09 
This is an author-produced, peer-reviewed version of this article. The final, definitive version of this document can be found online at Canadian Journal of Economics. Published by Wiley on behalf of the Canadian Economics Association. Copyright restrictions may apply. doi: 10.1111/caje.12174

Arns, M., K.B. van der Heijden, L.E. Arnold and J.L. Kenemans (2013) "Geographic Variation in the Prevalence of Attention Deficit/Hyperactivity Disorder: The Sunny Perspective." Biological Psychiatry 74(8), 585-90

Baker, M., J. Gruber and K. Milligan (2008) "Universal Childcare, Maternal Labor Supply, and Family Wellbeing." Journal of Political Economy, 116, 709-45

Bauermeister, J. J., P.E. Shrout, R. Rafael, B. Milagors, A. Margarita, A. Martinez-Tabloas, L. Chavez, M. RubioStipc, P. Garcia, J. Ribera and G. Canino (2007) “ADHD Correlates, Comorbidity, and Impairment in Community and Treated Samples of Children and Adolescents. Journal of Abnormal Child Psychology 35, 883-98

Bedard, K., and E. Dhuey (2006) "The Persistence of Early Childhood Maturity: International Evidence of LongRun Age Effects.” The Quarterly Journal of Economics 1437-572

Bertrand, M., and J. Pan (2013) "The Trouble with Boys: Social Influences and the Gender Gap in Disruptive Behavior." American Economic Journal: Applied Economics 5(1), 32-64

Black, S., P. Devereux and K. G. Salvanes (2011) "Too Young to Leave the Nest? The Effects of School Starting Age." Review of Economics and Statistics 93(2), 455-67

Brault, M. C., and E. Lacourse (2012) "Prevalence of Prescribed Attention-Deficit Hyperactivity Disorder Medications and Diagnosis among Canadian Preschoolers and School-Age Children: 1994-2007." Canadian Journal of Psychiatry 57(2), 93-01

Buckles, K., and D. Hungerman (2013) "Season of Birth and Later Outcomes: Old Questions, New Answers." The Review of Economics and Statistics 95(3), 711-24

CDC (2010) "Mental Health in the United States: Increasing Prevalence of Parent- Reported Attention Deficit/Hyperactivity Disorder-United States, 2003-2007." MMWR, 59(44), 1439-443

Chan P.A., and T. Rabinowitz (2006) "A Cross-Sectional Analysis of Video Games and Attention Deficit Hyperactivity Disorder Symptoms in Adolescents.” Annals of General Psychiatry, 5, 16

Chang, Y., S. Liu, H. Yu and Y.H. Lee (2012) "Effect of Acute Exercise on Executive Function in Children with Attention Deficit Hyperactivity Disorder.” Archives of Clinical Neuropsychology 27, 223-37

Charach, A., E. Lin and T. To (2010) "Evaluating the Hyperactivity/Inattention Subscale of the National Longitudinal Survey of Children and Youth." Health Reports 21(2), 1-8

Clouder, C. (2006) "Early Childhood Literacy: A View from Europe." www.allianceforchildhood.org.uk

Conti, G., and J. Heckman (2012) "The Economics of Child Well-Being.” National Bureau of Economic Research Working Paper 18466

Cornelissen, T., C. Dustmann and C. Trentini (2013) "Early School Exposure, Test Scores, and Noncognitive Outcomes." Working Paper

Cortese, S., M. Angriman, C. Maffeis, P. Isnard, E. Konofal, M. Lecendreux, D. Purper-Ouakil, B. Vincenzi, B. D. Bernardina and M. Mouren (2008) "Attention-Deficit/Hyperactivity Disorder (ADHD) and Obesity: A Systematic Review of the Literature." Critical Reviews in Food Science and Nutrition 48(6), 524-37

Cunha, F., and J. Heckman (2009) "The Economics and Psychology of Inequality and Human Development." Journal of the European Economics Association 7(2-3), 320-64

Currie, J. (2011) "Inequality at Birth: Some Causes and Consequences." American Economic Review 101(3), 1-22

Currie, J. (2009) "Health, Wealthy, and Wise: Socioeconomic Status, Poor Health in Childhood, and Human Capital Development." Journal of Economic Literature 47(1), 87-22

Currie, J., and D. Almond (2011) "Human Capital Development before Age Five." Handbook of Labor Economics 4, 1315-486

Currie, J., and M. Stabile (2003) "Socioeconomic Status and Child Health: Why is the Relationship Stronger for Older Children?” American Economic Review (93), 1813-823

Currie, J., and M. Stabile (2006) "Child Mental Health and Human Capital Accumulation: The Case of ADHD.” Journal of Health Economics 25, 1094-118

Currie, J, M. Stabile and L. Jones (2013) "Do Stimulant Medications Improve Educational and Behavioural Outcomes for Children with ADHD?” National Bureau of Economics Research Working Paper No. 1905

Currie, J., M. Stabile, P. Manivong and L. L. Roos (2010) “Child Health and Young Adult Outcomes.” The Journal of Human Resources 45(3), 517-48

Daley, D., and J. Birchwood (2010) “ADHD and Academic Performance: Why Does ADHD Impact on Academic Performance and What Can be done to Support ADHD Children in the Classroom?” Child:Care, Health and Development 35(4), 455-64

Deming, D., and S. Dynarski (2008) “The Lengthening of Childhood.” National Bureau of Economics Research Working Paper 14124 
This is an author-produced, peer-reviewed version of this article. The final, definitive version of this document can be found online at Canadian Journal of Economics. Published by Wiley on behalf of the Canadian Economics Association. Copyright restrictions may apply. doi: 10.1111/caje.12174

Dhuey, E., and S. Lipscomb (2010) “Disabled or Young? Relative Age and Special Education Diagnoses in Schools.” Economics of Education Review 29, 857-872

Dobkin, C., and F. Ferreira (2009) "Do School Entry Laws Affect Educational Attainment and Labor Market Outcomes?” Economics of Education Review 29, 40-54

Drolet, M. (2011) "Why has the Gender Wage Gap Narrowed?” Perspectives on Labour and Income Spring, 3-14

Elder, T. E. (2010) "The Importance of Relative Standards in ADHD Diagnosis: Evidence Based on Exact Birth Dates." Journal of Health Economics 29, 641-656

Evans, W. N., M. S. Morrill and S. T. Parente (2010) "Measuring Inappropriate Medical Diagnosis and Treatment in Survey Data: The Case of ADHD among School-Age Children.” The Journal of Health Economics 29, 657-673

Faraone, S. V., J.Sergeant, J., C. Gillberg and J. Biederman (2003) "The Worldwide Prevalence of ADHD: Is It an American Condition?" World Psychiatry 2(2), 104-13

Fletcher, J. (2013) “The Effects of Childhood ADHD on Adult Labor Market Outcomes.” National Bureau of Economics Research Working Paper 18689

Fletcher, J., and B. Wolfe (2008) "Child Mental Health and Human Capital Accumulation: The Case of ADHD Revisited.” Journal of Health Economics 27, 794-800

Fortin, N., P. Oreopoulos and S. Philips (2013) "Leaving Boys Behind: Gender Disparities in High Academic Achievement.” National Bureau of Economics Research Working Paper No. 19331

Frazier, T. W., E. A. Youngstrom, J. J. Glutting, and M. W. Watkins (2007) “ADHD and Achievement: MetaAnalysis of the Child, Adolescent and Adult Literatures and a Concomitant Study With College Students.” Journal of Learning Disabilities 40(1), 49-65

Galéra C., S. M. Côté, M. P. Bouvard, J. B. Pingault, M. Melchior, M. Boivin and M. G. Tremblay (2011) "Early Factors for Hyperactivity-Impulsivity and Inattention Trajectories from Age 17 Months to 8 Years." Archives of General Psychiatry 68(12), 1267-275

Garfield, C.F., E.R. Dorsey, S. Zhu, H.A. Huskamp, R.Conti, S.B. Dusetzina, A., Higashi, J.M. Perrin, R. Kornfield and G.C. Alexander (2012) "Trends in Attention Deficit Hyperactivity Disorder Ambulatory Diagnosis and Medical Treatment in the United States, 2000-2010." Academic Pediatrics. 12(2), 110-116.

Gershon, J., and J. Gershon (2002) "A Meta-Analytic Review of Gender Differences in ADHD." Journal of Attention Disorders 5(3), 143-54

Getahun, D., S. J. Jacobsen, M. J. Fassett, W. Chen, K. Demissie, D. G. Rhodes (2013) "Recent Trends in Childhood Attention-Deficit Hyperactivity Disorder." Journal of the American Medical Association. Pediatrics 167 (3), 282-88

Gurian, M. (2009) The Purpose of Boys: Helping Our Sons Find Meaning, Significance, and Direction in Their Lives. San Francisco: Jossey-Bass

Halperin, J. M., D. M. Healthy (2011) "The Influences of Environmental Enrichment, Cognitive Enhancement, and Physical Exercise on Brain Development: Can We Alter the Developmental Trajectory of ADHD?” Neuroscience and Biobehavioral Reviews 35, 621-34

Ivis, F. J., and E. M. Adlaf (1999) "Prevalence of Methylphenidate Use among Adolescents in Ontario,” Canadian Journal of Public Health 90(5), 309-312

Lee, D. S., and T. Lemieux (2010) "Regression Discontinuity Designs in Economics." Journal of Economic Literature 48(2), 281-55

Lefebvre, P, and P. Merrigan (2008) "Child-Care Policy and the Labor Supply of Mothers with Young Children: A Natural Experiment from Canada,” Journal of Labor Economics 26(3), 519-47

Lefebvre, P., P. Merrigan and M. Verstraete (2009) "Dynamic Labour Supply Effects of Childcare Subsidies: Evidence from a Canadian Natural Experiment on Low-Fee Universal Child Care.” Labour Economics 16(5), 490-02

Lingineni, R. K., S. Biswas, N. Ahmad, B. E. Jackson, S. Bae, S. and K. P. Singh (2012) Factors Associated with Attention Deficit/Hyperactivity Disorder among US Children: Results from a National Survey. Biomedical Central Pediatrics 12(1), 50

Loe, I. M., and H. M. Feldman (2007) “Academic and Educational Outcomes of Children with ADHD.” Journal of Pediatric Psychology 32(6), 643-54

Loe, I. M., M. D. Balestrino, R. A. Phelps, M. Kurs-Lasky, D. Chaves-Gnecco, P. Diego, L. Jack and H. M. Feldman (2008) "Early Histories of School-Aged Children with Attention-Deficit/Hyperactivity Disorder." Child Development 79(6), 1853-868

Mahone, E. M., and E. L. Wodka (2008) “The Neurobiological Profile of Girls with ADHD.” Developmental Disabilities Research Reviews 14, 276-84 
This is an author-produced, peer-reviewed version of this article. The final, definitive version of this document can be found online at Canadian Journal of Economics. Published by Wiley on behalf of the Canadian Economics Association. Copyright restrictions may apply. doi: 10.1111/caje.12174

Medina, J.A., T. L. B. Netto, M. Muszkat, A. C. Medina, D. Botter, R. Orbetelli, L. F. C. Scaramuzza, E. G. Sinnes, M. Vilela, and M. C. Miranda (2010) "Exercise Impact on Sustained Attention of ADHD Children, Methylphenidate Effects.” Attention Deficit HyperActivity Disorder 2, 49-58

Morrow, R. L., J. Garland, J. Wright, M. Maclure, S. Tayler and C. Dormuth (2012) "Influence of Relative Age on Diagnosis and Treatment of Attention-Deficit/Hyperactivity Disorder in Children.” Canadian Medical Association Journal 184(7), 755-761

Oreopoulos, P. (2005) "Canadian Compulsory School Laws and their Impact on Educational." Analytical Studies Branch Research Paper Series, Statistics Canada, Catalogue 11F0019MIE

Oreopoulos, P. (2006) "Estimating Average and Local Average Treatment Effects of Education when Compulsory Schooling Laws Really Matter,” American Economic Review 96(1), 152-175

Perrin, J. M., S. R. Bloom and S. L. Gortmaker (2007) "The Increase of Childhood Chronic Conditions in the United States.” Journal of the American Medical Association 297(24), 2755-759

Phipps, S. (2010) “Canadian Policies for Families with Very Young Children in International Perspective” in From Child Welfare to Child Well-being: An International Perspective on Knowledge in the Service of Making Policy. A special volume in honor of Alfred Kahn. Sheila Kamerman, Shelley Phipps and Asher Ben-Arieh (Editors), Springer Press, 309-38

Rogers, S., and J. Rose (2007) "Ready for Reception: The Advantages and Disadvantages of a Single-Point Entry to School." Early Years: An International Research Journal 27(4), 47-63

Romano, E., R. E. Tremblay, A. Farhat and S. Cote (2006) "Development and Prediction of Hyperactive Symptoms from 2 to 7 Years in a Population-Based Sample.” Pediatrics 227, 2101-110

Russell, G., L. R. Rodgers, O. Ukoumunne and T. Ford (2013) "Prevalence of Parent-Reported ASD and ADSD in the UK: Results from the UK Millenium Study. Journal of Autism and Developmental Disorders 44(1), 3140

Sax, L. (2007) Boys Adrift: The Five Factors Driving the Growing Epidemic of Unmotivated Boys and Underachieving Young Men. New York: Basic Books

Skounti, M., A. Philalithis, and E. Galanakis (2007) "Variations in Prevalence of Attention Deficit Hyperactivity Disorder Worldwide.” European Journal of Pediatrics 166, 177-23

Smith, J. (2009) "Can Regression Discontinuity Help Answer an Age-Old Question in Education? The Effect of Age on Elementary and Secondary School Achievement." The BE Journal of Economic Analysis \& Policy 9(1)

Spencer, T. J., J. Biederman and E. Mick (2007) “Attention-Deficit/Hyperactivity Disorder: Diagnosis, Lifespan, Comorbidities, and Neurobiology.” Journal of Pediatric Psychology 32(6), 631-42

Tantillo, M., C. M. Kesick, G. W. Hynd and R. K. Dishman (2002) “The Effects of Exercise on Children with Attention-Deficit Hyperactivity Disorder.” Medicine \& Science in Sports \& Exercise

Toppari, J., and A. Juul (2010) “Trends in Puberty Timing in Humans and Environmental Modifiers.” Molecular and Cellular Endocrinology 324, 39-44

Waring M. E., and K. L. Lapane (2008) "Overweight in Children and Adolescents in Relation to AttentionDeficit/Hyperactivity Disorder: Results from a National Sample." Pediatrics 122, 1-6

Wilens, T. E., J. Biederman and T. J. Spencer (2002) “Attention Deficit/Hyperactivity Disorder Across the Lifespan.” Annual Review of Medicine 53, 113-31 
This is an author-produced, peer-reviewed version of this article. The final, definitive version of this document can be found online at Canadian Journal of Economics. Published by Wiley on behalf of the Canadian Economics Association. Copyright restrictions may apply. doi: 10.1111/caje.12174
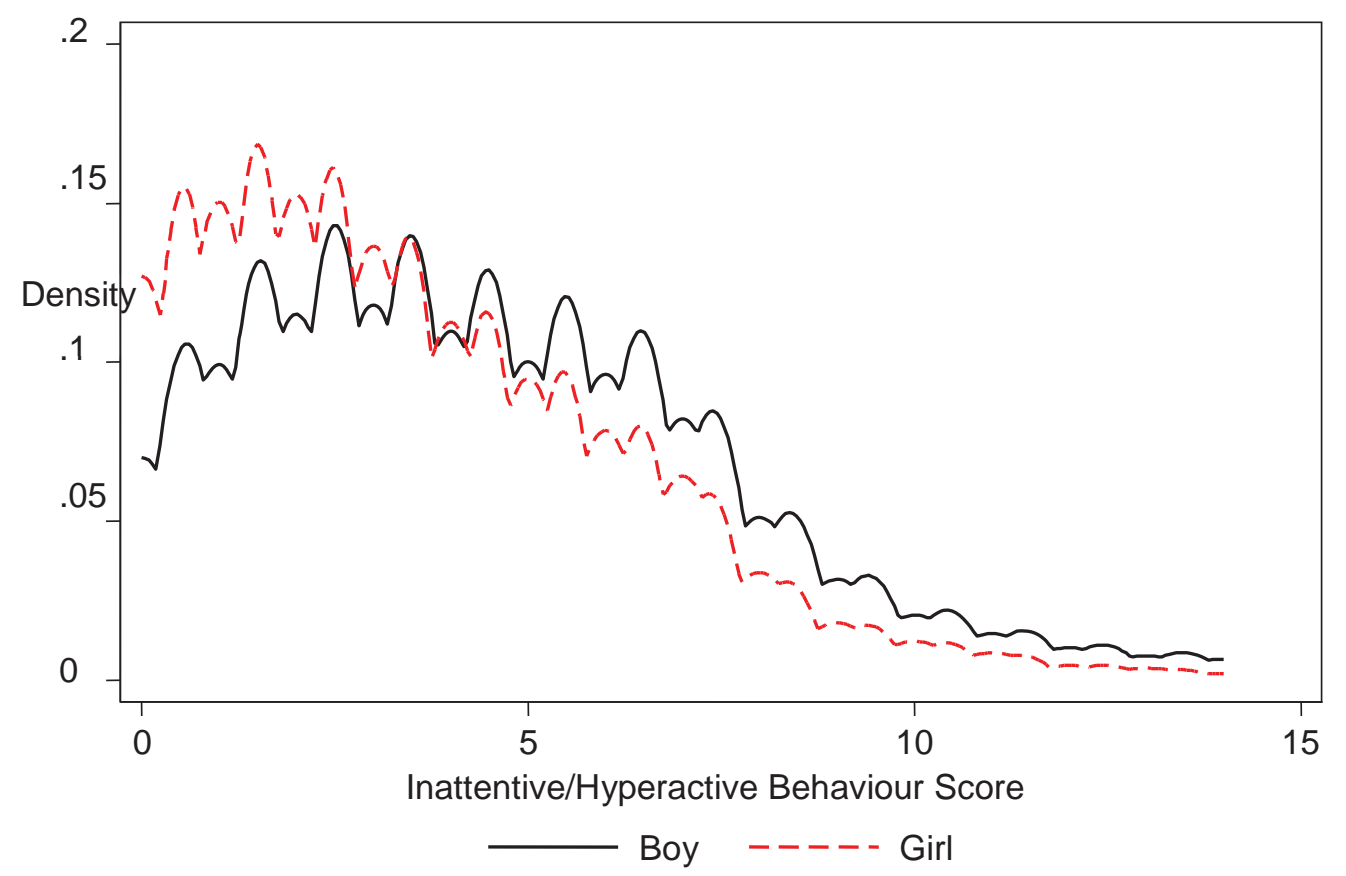

FIGURE 1 Distribution of inattentive/hyperactive scores for children aged 5 to 8 
This is an author-produced, peer-reviewed version of this article. The final, definitive version of this document can be found online at Canadian Journal of Economics. Published by Wiley on behalf of the Canadian Economics Association. Copyright restrictions may apply. doi: 10.1111/caje.12174

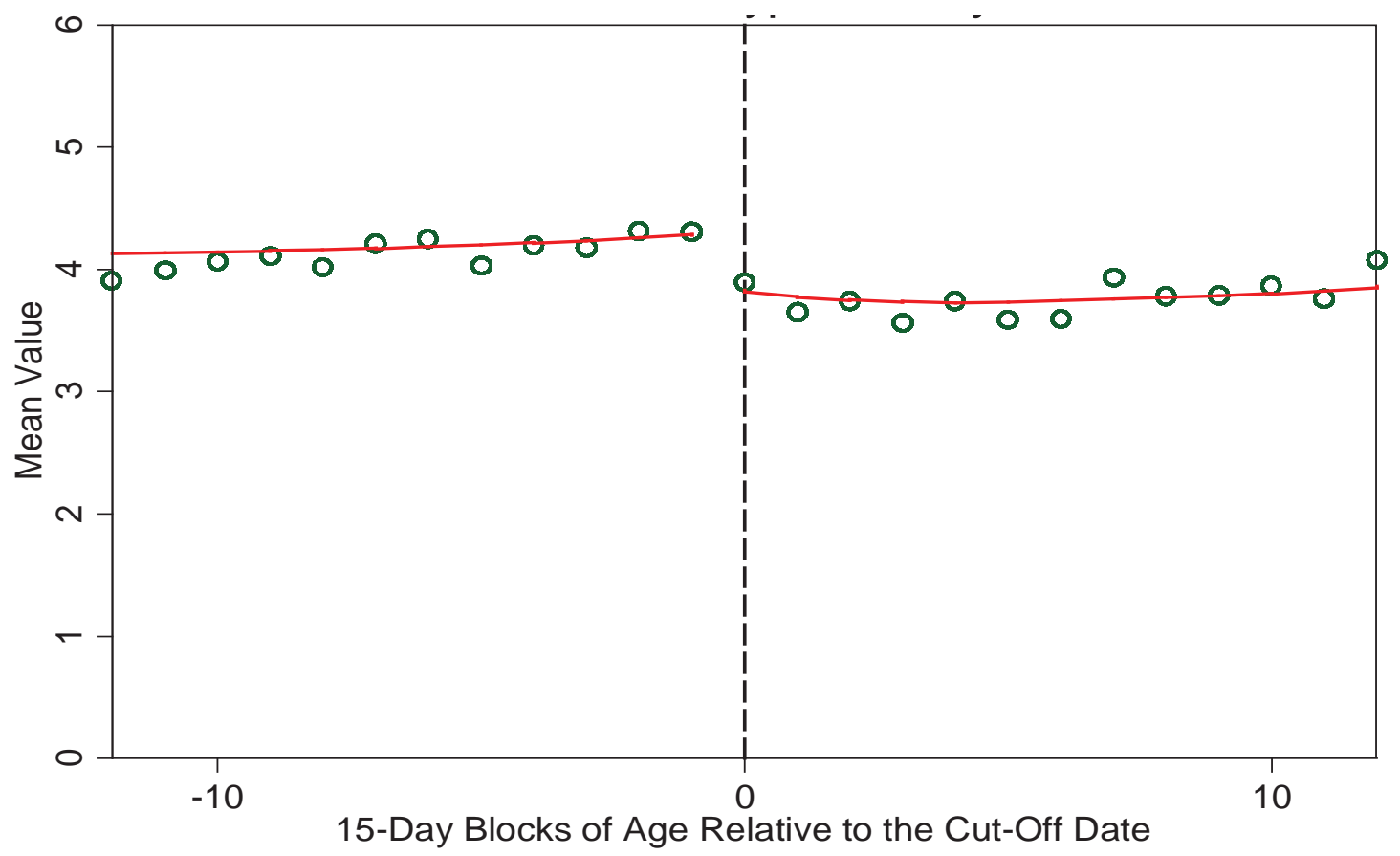

FIGURE 2 Discontinuity in inattention/hyperactivity at school start date at ages 5 to 8 for boys and girls

NOTE: Each circle represents the average hyperactivity score by 15-day blocks of age for all children aged between 5-8 years from 1994-2008 in the NLSCY. Relative age of zero (i.e. the middle of the x-axis) is the school entry age cut-off date for a province at a point in time when the child was $4 / 5$ years old. The curve is predicted from a linear regression fitted on un-weighted individual observations that additionally controls for school grade, cycle dummies, province dummies and a third-order polynomial of the forcing variable (i. e days from cut-off). 

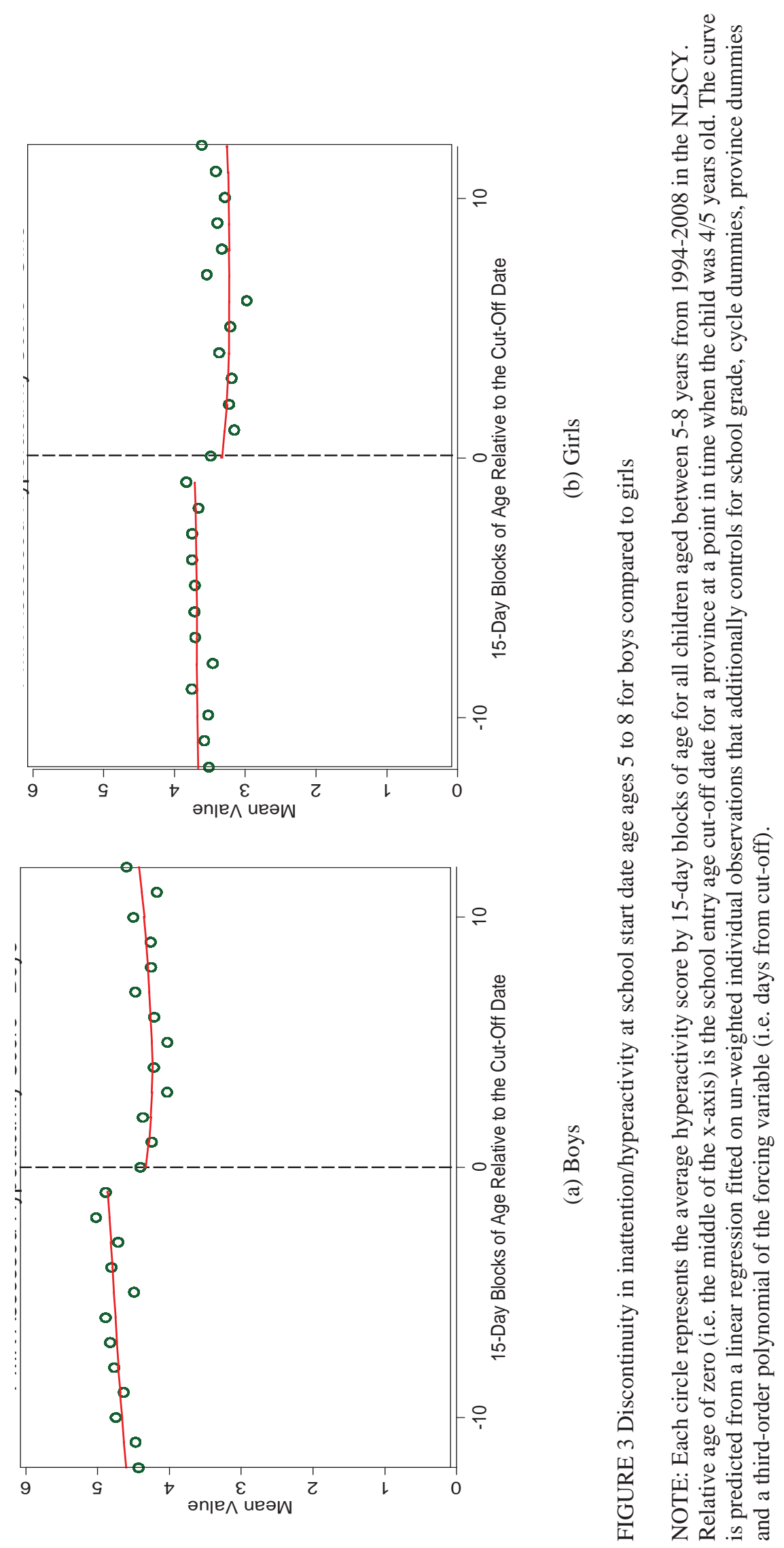
This is an author-produced, peer-reviewed version of this article. The final, definitive version of this document can be found online at Canadian Journal of Economics. Published by Wiley on behalf of the Canadian Economics Association. Copyright restrictions may apply. doi: 10.1111/caje.12174

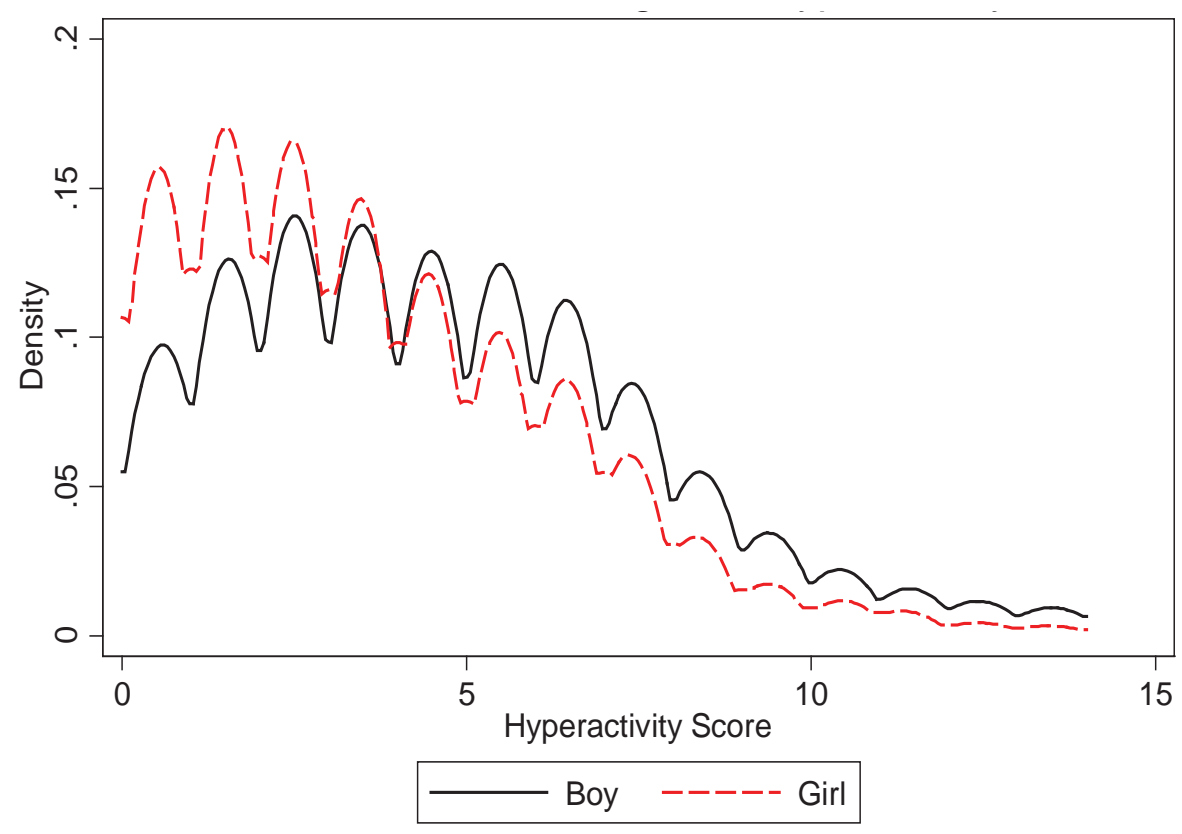

FIGURE 4 Distributions of inattention/hyperactive scores at ages 2/3 for boys compared to girls 
This is an author-produced, peer-reviewed version of this article. The final, definitive version of this document can be found online at Canadian Journal of Economics. Published by Wiley on behalf of the Canadian Economics Association. Copyright restrictions may apply. doi: 10.1111/caje.12174
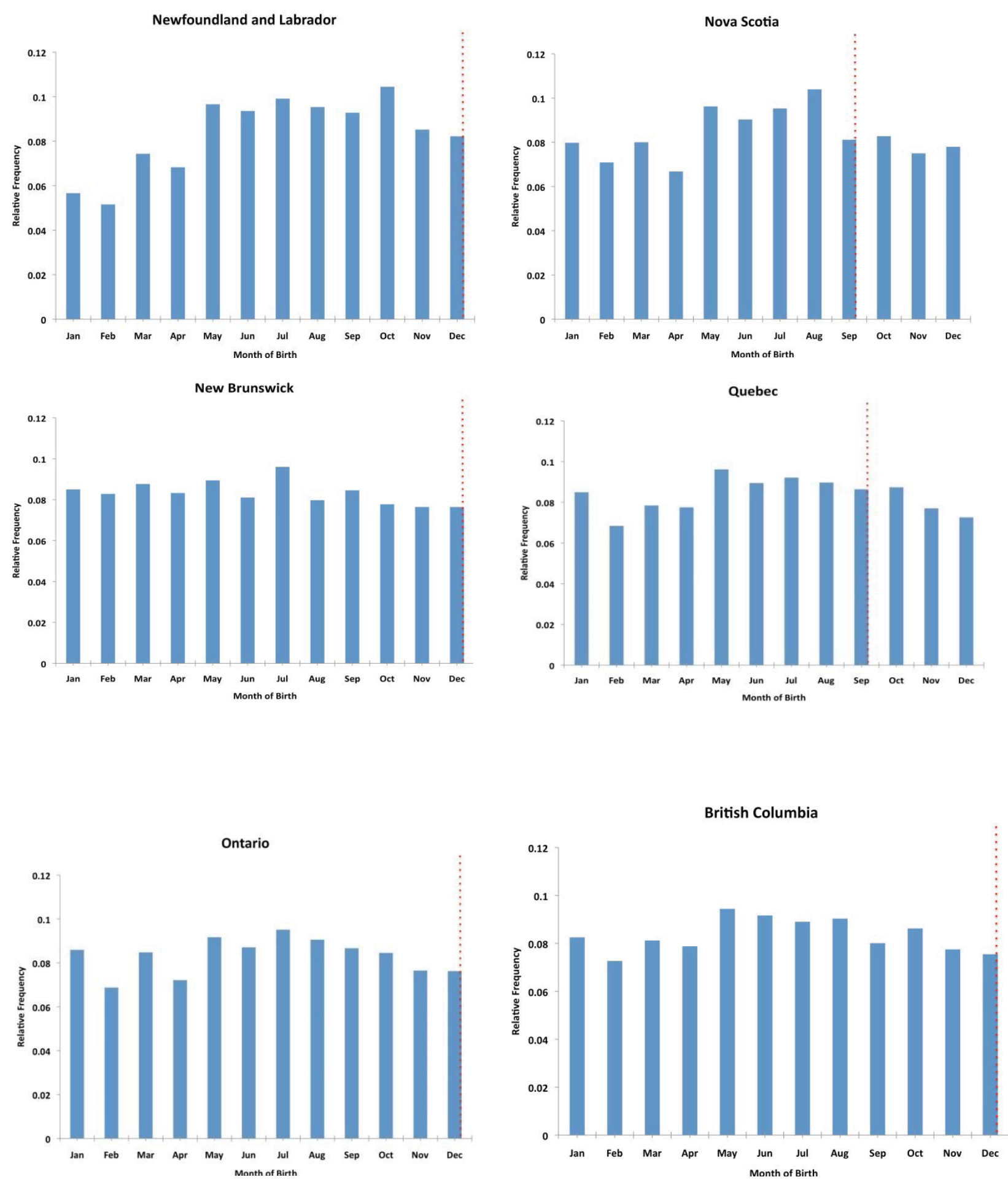

FIGURE 5 Birth Frequencies by month 
This is an author-produced, peer-reviewed version of this article. The final, definitive version of this document can be found online at Canadian Journal of Economics. Published by Wiley on behalf of the Canadian Economics Association. Copyright restrictions may apply. doi: 10.1111/caje.12174

TABLE 1

Cut-off dates for entry into kindergarten in 8 provinces and school boards/CMAs of Alberta and Saskatchewan (1994 to 2008)

\begin{tabular}{ll}
\hline Date & Provinces (School Boards / Years) \\
\hline September 1 & Alberta (Calgary) \\
September 30 & Quebec, Nova Scotia, PEI (2006) \\
October 31 & PEI (2005 and 2008) \\
November 30 & PEI (2004) \\
December 1 & Manitoba (1994-1996) \\
December 31 & British Columbia, Ontario, Saskatchewan (7 school boards/CMAs), Manitoba \\
& (1997-2000), New Brunswick, Newfoundland and Labrador, \\
January 31 & Alberta (Lethbridge, Red Deer, Lloydminster, Grande Prairie, Wetaskiwin) \\
Last Day of February & PEI (1994-2002) \\
March 1 & Alberta (Medicine Hat) \\
\hline
\end{tabular}

NOTE: The 7 school boards/CMAs in Saskatchewan include Regina -Regina District School Division, Yorkton Yorkton School Division, Moose Jaw - Moose Jaw School Division, Swift Current - Swift Current School Division, Saskatoon - Saskatoon District School Division, North Battleford - Battleford School Division, Prince Albert (cannot be linked with any school division, judging from the name so is not used in the analysis), and Estevan - Estevan School Division. 
This is an author-produced, peer-reviewed version of this article. The final, definitive version of this document can be found online at Canadian Journal of Economics. Published by Wiley on behalf of the Canadian Economics Association. Copyright restrictions may apply. doi: 10.1111/caje.12174

TABLE 2

Difference in difference estimates of the effect of being "young in class" on inattentive behaviour at 5/8 for children in public schools

\begin{tabular}{|c|c|c|c|c|c|c|}
\hline & $\begin{array}{l}\text { Boys+Girls } \\
\text { OLS }\end{array}$ & $\begin{array}{l}\text { Boys } \\
\text { OLS }\end{array}$ & $\begin{array}{l}\text { Girls } \\
\text { OLS }\end{array}$ & $\begin{array}{l}\text { Boys+Girls } \\
\text { Sibling FE }\end{array}$ & $\begin{array}{l}\text { Brother - } \\
\text { Brother FE }\end{array}$ & $\begin{array}{c}\text { Sister - Sister } \\
\text { FE }\end{array}$ \\
\hline $\begin{array}{l}\text { Mean Score } \\
\text { (St Deviation) }\end{array}$ & $\begin{array}{c}4.109 \\
(3.029)\end{array}$ & $\begin{array}{c}4.628 \\
(3.153)\end{array}$ & $\begin{array}{c}3.577 \\
(2.797)\end{array}$ & & & \\
\hline Young in Class & $\begin{array}{c}0.417 * * \\
(0.136)\end{array}$ & $\begin{array}{l}0.503^{* *} \\
(0.214)\end{array}$ & $\begin{array}{c}0.337 * * * \\
(0.059)\end{array}$ & $\begin{array}{l}0.725 * * \\
(0.246)\end{array}$ & $\begin{array}{c}1.014^{* * *} \\
(0.293)\end{array}$ & $\begin{array}{l}0.943 * * \\
(0.386)\end{array}$ \\
\hline Boy & $\begin{array}{c}1.054^{* * *} \\
(0.031)\end{array}$ & -- & -- & $\begin{array}{c}1.265^{* * *} \\
(0.071)\end{array}$ & -- & -- \\
\hline First-Born & $\begin{array}{l}0.147 * * * \\
(0.0323) \\
\end{array}$ & $\begin{array}{l}-0.016 \\
(0.107) \\
\end{array}$ & $\begin{array}{c}0.317 * * * \\
(0.071) \\
\end{array}$ & $\begin{array}{c}-0.475 * * \\
(0.205)\end{array}$ & $\begin{array}{c}-0.467 * * \\
(0.185)\end{array}$ & $\begin{array}{l}-0.822^{* *} \\
(0.326)\end{array}$ \\
\hline Born First Quarter & $\begin{array}{c}0.005 \\
(0.147)\end{array}$ & $\begin{array}{c}0.120 \\
(0.254)\end{array}$ & $\begin{array}{l}-0.104 \\
(0.136)\end{array}$ & $\begin{array}{l}-0.114 \\
(0.306)\end{array}$ & $\begin{array}{c}0.329 \\
(0.497)\end{array}$ & $\begin{array}{c}0.259 \\
(0.852)\end{array}$ \\
\hline Born 2nd Quarter & $\begin{array}{c}0.027 \\
(0.131)\end{array}$ & $\begin{array}{c}0.133 \\
(0.164)\end{array}$ & $\begin{array}{l}-0.079 \\
(0.116)\end{array}$ & $\begin{array}{c}0.102 \\
(0.180)\end{array}$ & $\begin{array}{c}0.078 \\
(0.249)\end{array}$ & $\begin{array}{c}0.291 \\
(0.573)\end{array}$ \\
\hline Born 4th Quarter & $\begin{array}{l}-0.008 \\
(0.191)\end{array}$ & $\begin{array}{c}0.031 \\
(0.210)\end{array}$ & $\begin{array}{l}-0.045 \\
(0.183)\end{array}$ & $\begin{array}{c}0.018 \\
(0.130)\end{array}$ & $\begin{array}{c}0.136 \\
(0.165)\end{array}$ & $\begin{array}{c}0.060 \\
(0.321)\end{array}$ \\
\hline $\begin{array}{l}\text { Log Equivalent } \\
\text { Household Income }\end{array}$ & $\begin{array}{c}-0.177 * * \\
(0.059)\end{array}$ & $\begin{array}{c}-0.139 * * \\
(0.043)\end{array}$ & $\begin{array}{c}-0.220 * * \\
(0.082)\end{array}$ & & & \\
\hline PMK University & $\begin{array}{c}-0.743^{* * *} \\
(0.034)\end{array}$ & $\begin{array}{c}- \\
0.741 * * * \\
(0.074)\end{array}$ & $\begin{array}{c}-0.748^{* * *} \\
(0.048)\end{array}$ & & & \\
\hline PMK College Diploma & $\begin{array}{c}-0.393^{* * * *} \\
(0.110)\end{array}$ & $\begin{array}{l}-0.324 \\
(0.208)\end{array}$ & $\begin{array}{c}-0.473 * * * \\
(0.083)\end{array}$ & & & \\
\hline PMK High School & $\begin{array}{c}-0.287 * * \\
(0.116)\end{array}$ & $\begin{array}{l}-0.286 \\
(0.239)\end{array}$ & $\begin{array}{c}-0.287 * * * \\
(0.083)\end{array}$ & & & \\
\hline Step Family & $\begin{array}{c}0.776 * * * \\
(0.055)\end{array}$ & $\begin{array}{c}0.875 * * * \\
(0.152)\end{array}$ & $\begin{array}{c}0.665 * * * \\
(0.080)\end{array}$ & & & \\
\hline Lone Parent Family & $\begin{array}{c}0.507 * * * \\
(0.084)\end{array}$ & $\begin{array}{c}0.615^{* * *} \\
(0.091)\end{array}$ & $\begin{array}{l}0.382 * * * \\
(0.084)\end{array}$ & & & \\
\hline PMK Immigrant & $\begin{array}{c}-0.273^{* * *} \\
(0.056)\end{array}$ & $\begin{array}{c}0.399 * * * \\
(0.010)\end{array}$ & $\begin{array}{c}-0.150 * * \\
(0.064)\end{array}$ & & & \\
\hline Child Age in Months & $\begin{array}{c}0.176 \\
(0.136)\end{array}$ & $\begin{array}{c}0.055 \\
(0.236)\end{array}$ & $\begin{array}{c}0.161 \\
(0.176)\end{array}$ & $\begin{array}{c}0.089 \\
(0.733)\end{array}$ & $\begin{array}{l}-0.211 \\
(1.451)\end{array}$ & $\begin{array}{l}-2.108^{* *} \\
(0.715)\end{array}$ \\
\hline $\begin{array}{l}\text { Child Age in Months } \\
\text { Squared }\end{array}$ & $\begin{array}{l}-0.002 \\
(0.002)\end{array}$ & $\begin{array}{l}-0.0002 \\
(0.003)\end{array}$ & $\begin{array}{l}-0.001 \\
(0.002)\end{array}$ & $\begin{array}{l}-0.0005 \\
(0.009)\end{array}$ & $\begin{array}{c}0.003 \\
(0.017)\end{array}$ & $\begin{array}{c}0.028 * * \\
(0.009)\end{array}$ \\
\hline $\begin{array}{l}\text { Child Age in Months } \\
\text { Cubed }\end{array}$ & $\begin{array}{c}3.78 \mathrm{e}-06 \\
(5.55 \mathrm{e}-06)\end{array}$ & $\begin{array}{c}-7.84 \mathrm{e}- \\
07 \\
(1.21 \mathrm{e}- \\
05)\end{array}$ & $\begin{array}{c}1.20 \mathrm{e}-06 \\
(7.95 \mathrm{e}- \\
06)\end{array}$ & $\begin{array}{c}5.84 \mathrm{e}-08 \\
(3.47 \mathrm{e}-05)\end{array}$ & $\begin{array}{l}-1.62 \mathrm{e}-05 \\
(6.83 \mathrm{e}-05)\end{array}$ & $\begin{array}{c}-1.18 \mathrm{e}-04^{* * * *} \\
(3.39 \mathrm{e}-05)\end{array}$ \\
\hline $\begin{array}{l}\text { Number of } \\
\text { Observations }\end{array}$ & 25196 & 12729 & 12467 & 3986 & 1120 & 1048 \\
\hline
\end{tabular}

NOTE: These models also include but do not report NLSCY cycle. Robust standard errors clustered at the provincial level are reported in parentheses. Sample: Children with an effective age from 5 to 8 years, who attend public school, who were also present in the data at age $4 / 5$ and have not moved inter-provincially since then. Children can appear more than once in the data set. For sibling fixed effects estimates, sibling pairs are selected if both children satisfy these conditions. *** indicates statistical significance at $1 \%$ level; ** at $5 \%$; * at $10 \%$. 
This is an author-produced, peer-reviewed version of this article. The final, definitive version of this document can be found online at Canadian Journal of Economics. Published by Wiley on behalf of the Canadian Economics Association. Copyright restrictions may apply. doi: 10.1111/caje.12174

TABLE 3

Difference in difference estimates of the effects of "young in class" on inattentive behaviour at 5/8 by socioeconomic status

\begin{tabular}{|l|c|c|c|}
\hline & $\begin{array}{c}\text { Children with Less } \\
\text { than Mean Income }\end{array}$ & $\begin{array}{c}\text { Children with } \\
\text { More than Mean } \\
\text { Income }\end{array}$ & All Children \\
\hline Young in Class & $0.601^{* * *}$ & $0.268^{* *}$ & $0.342^{* *}$ \\
$(0.103)$ & $(0.115)$ \\
\hline Less than Mean Income & & & 0.105 \\
& & & $(0.059)$ \\
\hline Young X Less than Mean Income & & & $0.176^{* *}$ \\
& & & $(0.076)$ \\
\hline Number of Observations & 11661 & 13535 & 25196 \\
\hline
\end{tabular}

NOTE: These models also include but do not report NLSCY cycle. Robust standard errors clustered at the provincial level are reported in parentheses. Sample: Children with an effective age from 5 to 8 years, who attend public school, who were also present in the data at age $4 / 5$ and have not moved inter-provincially since then. Children can appear more than once in the data set. *** indicates statistical significance at $1 \%$ level; ** at $5 \%$; * at $10 \%$.

TABLE 4

Regression discontinuity estimates of the effect of "young in class" on inattentive behaviour of boys and girls at age $5 / 8$

\begin{tabular}{|c|c|c|}
\hline & Boys+Girls & Boys+Girls \\
& 2-month window & 3-month window \\
\hline Mean Score & 4.118 & 4.099 \\
(St Deviation) & $(3.027)$ & $(3.026)$ \\
\hline Young in Class & $0.501^{* *}$ & $0.531^{* *}$ \\
& $(0.243)$ & $(0.207)$ \\
\hline \multirow{2}{*}{ Boy } & $0.994^{* * *}$ & $0.940^{* * *}$ \\
& $(0.108)$ & $(0.088)$ \\
\hline Number of Observations & 8127 & 12441 \\
\hline
\end{tabular}

NOTE: These estimates use a linear running variable, $\mathrm{f}\left(\mathrm{bd}_{\mathrm{i}}-\mathrm{C}_{\mathrm{i}}\right)$. Models also include grade, in a cubic specification, child gender, birth order, (log of) family income, parental education, family structure, immigrant status as well as province and NLSCY cycle. Robust standard errors clustering at distance from the cut-off are reported in parentheses. Sample: Children with an effective age from 5 to 8 years, who attend public school, who were also observed when they were age 4/5 and have not moved inter-provincially since then and whose birth date falls 2 months (or 3 months) on either side of the school start cut-off for that province/year. Children can appear more than once in the data set. *** indicates statistical significance at $1 \%$ level; ** at $5 \%$; * at $10 \%$. 
This is an author-produced, peer-reviewed version of this article. The final, definitive version of this document can be found online at Canadian Journal of Economics. Published by Wiley on behalf of the Canadian Economics Association. Copyright restrictions may apply. doi: 10.1111/caje.12174

TABLE 5

Robustness of difference in difference estimates of the effect of being "young in class" on inattentive behaviour to alternative samples

\begin{tabular}{|c|c|c|c|c|c|}
\hline & $\begin{array}{c}\text { Basic } \\
\text { Estimating } \\
\text { Sample }\end{array}$ & $\begin{array}{c}\text { Children with } \\
\text { Above Mean } \\
\text { Score }\end{array}$ & $\begin{array}{c}\text { Children with } \\
\text { Below Mean } \\
\text { Score }\end{array}$ & $\begin{array}{c}\text { Adding } \\
\text { Children not in } \\
\text { Public School }\end{array}$ & $\begin{array}{c}\text { Restricting to } \\
\text { Children } \\
\text { Observed } \\
\text { Since 3/4 }\end{array}$ \\
\hline $\begin{array}{c}\text { Mean Score } \\
\text { (St Deviation) }\end{array}$ & $\begin{array}{c}4.109 \\
(3.029)\end{array}$ & $\begin{array}{c}7.154 \\
(2.135)\end{array}$ & $\begin{array}{c}2.060 \\
(1.354)\end{array}$ & $\begin{array}{c}4.093 \\
(3.023)\end{array}$ & $\begin{array}{c}4.120 \\
(3.021)\end{array}$ \\
\hline Young in Class & $\begin{array}{c}0.417^{* *} \\
(0.136)\end{array}$ & $\begin{array}{c}0.370^{* * *} \\
(0.038)\end{array}$ & $\begin{array}{c}0.045 \\
(0.042)\end{array}$ & $\begin{array}{c}0.435^{* *} \\
(0.134)\end{array}$ & $\begin{array}{c}0.377^{* *} \\
(0.131)\end{array}$ \\
\hline Boy & $\begin{array}{c}1.054^{* * *} \\
(0.031)\end{array}$ & $\begin{array}{c}0.502^{* * *} \\
(0.098)\end{array}$ & $\begin{array}{c}0.251^{* * *} \\
(0.035)\end{array}$ & $\begin{array}{c}1.043^{* * *} \\
(0.034)\end{array}$ & $\begin{array}{c}1.073^{* * *} \\
(0.062)\end{array}$ \\
\hline Attended JK & & & & & $\begin{array}{c}-0.036 \\
(0.072)\end{array}$ \\
\hline Attended Formal & & & & & $0.353^{* * *}$ \\
Daycare at Age 3/4 & & 10075 & 15121 & 26327 & 23041 \\
\hline $\begin{array}{c}\text { Number of } \\
\text { Observations }\end{array}$ & 25196 & & & \\
\hline
\end{tabular}

NOTE: These models also include but do not report child age and age squared family income, parental education, family structure, immigrant status and NLSCY cycle. Robust standard errors clustered at the provincial level are reported in parentheses. *** indicates statistical significance at $1 \%$ level; ** at $5 \%$; * at $10 \%$. 
This is an author-produced, peer-reviewed version of this article. The final, definitive version of this document can be found online at Canadian Journal of Economics. Published by Wiley on behalf of the Canadian Economics Association. Copyright restrictions may apply. doi: 10.1111/caje.12174

TABLE 6

Difference in difference estimates of the effect of being "young in class" on inattentive behaviour at 5/8 while controlling for hyperactive/inattentive behaviour at 2/3.

\begin{tabular}{|c|c|c|c|c|}
\hline & $\begin{array}{l}(1) \\
\text { OLS }\end{array}$ & $\begin{array}{l}(2) \\
\text { OLS }\end{array}$ & $\begin{array}{c}\text { (3) } \\
\text { Sibling FE }\end{array}$ & $\begin{array}{l}\text { (4) } \\
\text { OLS }\end{array}$ \\
\hline Young in Class & -- & $\begin{array}{c}0.411^{* *} \\
(0.142)\end{array}$ & $\begin{array}{c}0.703^{* *} \\
(0.251)\end{array}$ & $\begin{array}{c}4.138 \\
(3.001)\end{array}$ \\
\hline Boy & $\begin{array}{c}0.891 * * * \\
(0.054)\end{array}$ & $\begin{array}{c}0.893 * * * \\
(0.057)\end{array}$ & $\begin{array}{c}1.151^{* * *} \\
(0.168)\end{array}$ & $\begin{array}{c}0.924^{* * * *} \\
(0.059)\end{array}$ \\
\hline Inattentive Score at $2 / 3$ & $\begin{array}{c}0.405^{* * *} \\
(0.003)\end{array}$ & $\begin{array}{c}0.404^{* * *} \\
(0.003)\end{array}$ & $\begin{array}{c}0.289 * * * \\
(0.039)\end{array}$ & $\begin{array}{c}0.325 \\
(0.230)\end{array}$ \\
\hline \multicolumn{5}{|l|}{ Quartile of I/H Score at $2 / 3$} \\
\hline Second & & & & $\begin{array}{c}0.975^{* * *} \\
(0.143)\end{array}$ \\
\hline Third & & & & $\begin{array}{c}1.623^{* * *} \\
(0.085)\end{array}$ \\
\hline Top & & & & $\begin{array}{c}2.607 * * * \\
(0.158)\end{array}$ \\
\hline \multicolumn{5}{|c|}{ I/H Quartile X Young Interactions } \\
\hline Second X Young & & & & $\begin{array}{c}-0.111 \\
(0.166)\end{array}$ \\
\hline Third X Young & & & & $\begin{array}{c}0.093 \\
(0.130)\end{array}$ \\
\hline Top X Young & & & & $\begin{array}{c}0.471^{* *} \\
(0.194)\end{array}$ \\
\hline Number of Observations & 20903 & 20903 & 2224 & 20903 \\
\hline
\end{tabular}

NOTE: OLS models also include but do not report child age in months in a cubic specification, birth order, quarter of birth, (log of) family equivalent income, parental education, family structure, immigrant status and NLSCY cycle. FE models include child age in months in a cubic specification, birth order, quarter of birth and NLSCY cyle. Robust standard errors clustered at the provincial level are reported in parentheses. Sample: Children with an effective age from 5 to 8 years, who attend public school, with a reported I/H score at age 2/3, who were also present in the data at age $4 / 5$ and have not moved inter-provincially since then. Children can appear more than once in the data set. For sibling fixed effects estimates, sibling pairs are selected if both children satisfy these conditions. *** indicates statistical significance at $1 \%$ level; ** at $5 \%$; * at $10 \%$. 
This is an author-produced, peer-reviewed version of this article. The final, definitive version of this document can be found online at Canadian Journal of Economics. Published by Wiley on behalf of the Canadian Economics Association. Copyright restrictions may apply. doi: 10.1111/caje. 12174

TABLE 7

OLS estimates of inattentive/hyperactive at 2/3 on an indicator of whether or not children will be "young in class" when they enter school (falsification test)

\begin{tabular}{|l|c|c|c|}
\hline & Boys+Girls & Boys & Girls \\
\hline Will be "Young in Class" & 0.033 & 0.132 & -0.071 \\
& $(0.036)$ & $(0.121)$ & $(0.098)$ \\
\hline Boy & $0.411^{* * *}$ & -- & -- \\
\hline Number of Observations & $(0.068)$ & & 10667 \\
\hline
\end{tabular}

Note: Models also include but do not report child age in months in a cubic specification, birth order, quarter of birth, (log of) family equivalent income, parental education, family structure, immigrant status and NLSCY cycle. Sample: Children with an effective age from 5 to 8 years, who attend public school, with a reported I/H score at age 2/3, who were also present in the data at age 4/5 and have not moved inter-provincially since then. Although children need not have an $\mathrm{I} / \mathrm{H}$ score at 5/8, responses to all other covariates must have been made. Children can appear more than once in the data set. *** indicates statistical significance at $1 \%$ level; ** at $5 \%$; $*$ at $10 \%$.

TABLE 8

Difference in difference estimates of the impact of being "young in class" on parent-reported outcomes of early adolescents

\begin{tabular}{|c|c|c|c|c|c|c|}
\hline & \multicolumn{2}{|c|}{$\begin{array}{c}\text { I/H Score for Children Aged } \\
10 / 11 \\
(0,14)\end{array}$} & \multicolumn{2}{|c|}{$\begin{array}{c}\text { Over-all Success at } \\
\text { School for Youth Aged } \\
14 / 15 \\
(1,5)\end{array}$} & \multicolumn{2}{|c|}{$\begin{array}{c}\text { Ever Repeated a Grade } \\
\text { for Youth Aged 14/15 } \\
\qquad(0,1)\end{array}$} \\
\hline & $\begin{array}{l}\text { Children } \\
\text { Observed } \\
\text { Since 4/5 }\end{array}$ & $\begin{array}{l}\text { Children } \\
\text { Observed } \\
\text { Since } 2 / 3\end{array}$ & $\begin{array}{l}\text { Children } \\
\text { Observed } \\
\text { Since } 4 / 5\end{array}$ & $\begin{array}{l}\text { Children } \\
\text { Observed } \\
\text { Since } 2 / 3\end{array}$ & $\begin{array}{l}\text { Children } \\
\text { Observed } \\
\text { Since } 4 / 5\end{array}$ & $\begin{array}{l}\text { Children } \\
\text { Observed } \\
\text { Since } 2 / 3\end{array}$ \\
\hline $\begin{array}{l}\text { Mean } \\
\text { (St Deviation) }\end{array}$ & $\begin{array}{c}3.477 \\
(3.092)\end{array}$ & $\begin{array}{c}3.577 \\
(3.151)\end{array}$ & $\begin{array}{c}4.049 \\
(0.947)\end{array}$ & $\begin{array}{c}4.067 \\
(0.938)\end{array}$ & $\begin{array}{c}0.070 \\
(0.255)\end{array}$ & $\begin{array}{c}0.082 \\
(0.275)\end{array}$ \\
\hline Young in Class & $\begin{array}{c}0.537 * * * \\
(0.128)\end{array}$ & $\begin{array}{l}0.498 * * \\
(0.162)\end{array}$ & $\begin{array}{c}-0.069 * * \\
(0.030)\end{array}$ & $\begin{array}{c}-0.081^{* *} \\
(0.033)\end{array}$ & $\begin{array}{c}0.034 * * * \\
(0.003)\end{array}$ & $\begin{array}{c}0.043^{* * *} \\
(0.003)\end{array}$ \\
\hline Boy & $\begin{array}{l}1.252 * * * \\
(0.061)\end{array}$ & $\begin{array}{c}1.118 * * * \\
(0.066)\end{array}$ & $\begin{array}{c}-0.319 * * * \\
(0.025)\end{array}$ & $\begin{array}{c}-0.260 * * * \\
(0.049)\end{array}$ & $\begin{array}{l}0.033 * * \\
(0.013)\end{array}$ & $\begin{array}{c}0.035 \\
(0.021)\end{array}$ \\
\hline $\begin{array}{l}\text { Inattentive/Hyperactive } \\
\text { Score at } 2 / 3\end{array}$ & & $\begin{array}{c}0.308 * * * \\
(0.039)\end{array}$ & & $\begin{array}{c}-0.034^{* * * *} \\
(0.006)\end{array}$ & & $\begin{array}{l}0.007 * \\
(0.003)\end{array}$ \\
\hline Number of Observations & 5316 & 3803 & 4606 & 3283 & 4601 & 3281 \\
\hline
\end{tabular}

NOTE: Models also include but do not report child age in months in a cubic specification, birth order, quarter of birth, (log of) family equivalent income, parental education, family structure, immigrant status and NLSCY cycle. *** indicates statistical significance at $1 \%$ level; ** at $5 \%$; at $10 \%$. 
This is an author-produced, peer-reviewed version of this article. The final, definitive version of this document can be found online at Canadian Journal of Economics. Published by Wiley on behalf of the Canadian Economics Association. Copyright restrictions may apply. doi: $10.1111 /$ caje. 12174

TABLE 9

Sibling fixed effects difference in difference estimates of the impact of being young at school on parent-reported outcomes of early adolescents

\begin{tabular}{|c|c|c|c|c|c|c|}
\hline & \multicolumn{2}{|c|}{$\begin{array}{c}\text { I/H Score for Children } \\
\text { Aged 10/11 } \\
(0,14) \\
\end{array}$} & \multicolumn{2}{|c|}{$\begin{array}{c}\text { Over-all Success at School } \\
\text { for Youth Aged 14/15 } \\
(1,5)\end{array}$} & \multicolumn{2}{|c|}{$\begin{array}{c}\text { Ever Repeated a Grade for } \\
\text { Youth Aged 14/15 } \\
(0,1)\end{array}$} \\
\hline & $\begin{array}{l}\text { Children } \\
\text { Observed } \\
\text { Since 4/5 }\end{array}$ & $\begin{array}{l}\text { Children } \\
\text { Observed } \\
\text { Since 2/3 }\end{array}$ & $\begin{array}{l}\text { Children } \\
\text { Observed } \\
\text { Since } 4 / 5\end{array}$ & $\begin{array}{l}\text { Children } \\
\text { Observed } \\
\text { Since } 2 / 3\end{array}$ & $\begin{array}{l}\text { Children } \\
\text { Observed } \\
\text { Since } 4 / 5\end{array}$ & $\begin{array}{l}\text { Children } \\
\text { Observed } \\
\text { Since } 2 / 3\end{array}$ \\
\hline $\begin{array}{l}\text { Mean } \\
\text { (Standard Deviation) }\end{array}$ & $\begin{array}{c}3.265 \\
(3.111)\end{array}$ & $\begin{array}{c}3.335 \\
(3.205)\end{array}$ & $\begin{array}{c}4.102 \\
(0.952)\end{array}$ & $\begin{array}{c}4.125 \\
(0.953)\end{array}$ & $\begin{array}{c}0.067 \\
(0.250)\end{array}$ & $\begin{array}{c}0.061 \\
(0.239)\end{array}$ \\
\hline Young in Class & $\begin{array}{c}0.399 \\
(0.238)\end{array}$ & $\begin{array}{l}0.703^{*} \\
(0.351)\end{array}$ & $\begin{array}{c}-0.212 * * \\
(0.045)\end{array}$ & $\begin{array}{l}-0.221 \\
(0.124)\end{array}$ & $\begin{array}{c}0.059 \\
(0.036)\end{array}$ & $\begin{array}{c}0.095^{* *} \\
(0.041)\end{array}$ \\
\hline Boy & $\begin{array}{c}1.340^{* * *} \\
(0.113)\end{array}$ & $\begin{array}{c}1.166^{* * * *} \\
(0.123)\end{array}$ & $\begin{array}{c}0.285^{* * *} \\
(0.091)\end{array}$ & $\begin{array}{c}-0.177 * * \\
(0.075)\end{array}$ & $\begin{array}{l}0.020^{* *} \\
(0.009)\end{array}$ & $\begin{array}{c}0.028 \\
(0.018)\end{array}$ \\
\hline $\begin{array}{l}\text { Inattentive/Hyperactive } \\
\text { Score at } 2 / 3\end{array}$ & & $\begin{array}{c}0.273^{* * *} \\
(0.031)\end{array}$ & & $\begin{array}{c}-0.060^{* * *} \\
(0.012)\end{array}$ & & $\begin{array}{c}0.005 \\
(0.004)\end{array}$ \\
\hline Number of Sibling Pairs & 1095 & 581 & 891 & 480 & 891 & 478 \\
\hline
\end{tabular}

NOTE: Sibling Fixed Effects models include child age in months in a cubic specification, birth order, quarter of birth and NLSCY cycle. Robust standard errors clustered at the provincial level are reported in parentheses *** indicates statistical significance at $1 \%$ level; ** at $5 \%$; * at $10 \%$.

\section{Appendix:}

TABLE A1

Example changes in relative age in class for children starting kindergarten (primary) in one province and moving to another province for start of grade one (i.e., maintaining grade progression)

\begin{tabular}{|c|c|c|}
\hline & $\mathrm{BC}$ & NS \\
\hline $\begin{array}{l}\text { Age Range for Children in Grade } 1 \\
\text { on September } 1\end{array}$ & $\begin{array}{c}5 \text { yrs }+8 \text { mos to } \\
6 \text { yrs } 8 \text { mos }\end{array}$ & $\begin{array}{l}5 \text { yrs } 11 \text { mos to } \\
6 \text { yrs } 11 \mathrm{mo}\end{array}$ \\
\hline Birth Date Youngest Child & Dec 30 & Sept 30 \\
\hline $\begin{array}{l}\text { Relative Age on Sept } 1 \text { of Youngest } \\
\text { Child in NS moving to BC and } \\
\text { continuing to Grade } 1\end{array}$ & $\begin{array}{l}3 \text { months older than youngest in BC } \\
\text { class; } 9 \text { months younger than oldest } \\
\text { in BC class }\end{array}$ & \\
\hline $\begin{array}{l}\text { Relative Age on Sept } 1 \text { of Youngest } \\
\text { Child Moving from BC to NS and } \\
\text { continuing to Grade } 1\end{array}$ & & $\begin{array}{l}3 \text { months younger than youngest in } \\
\text { NS class; } 15 \text { months younger than } \\
\text { oldest in NS class }\end{array}$ \\
\hline $\begin{array}{l}\text { Relative Age on Sept } 1 \text { of Oldest } \\
\text { Child in NS moving to BC and } \\
\text { continuing to Grade } 1\end{array}$ & $\begin{array}{c}15 \text { months older than youngest in } \\
\text { BC class; } 3 \text { months older than } \\
\text { oldest in BC class }\end{array}$ & \\
\hline $\begin{array}{l}\text { Relative Age on Sept } 1 \text { of Oldest } \\
\text { Child Moving from BC to NS and } \\
\text { continuing to Grade } 1\end{array}$ & & $\begin{array}{l}3 \text { months younger than oldest in NS } \\
\text { class; } 9 \text { months older than youngest } \\
\text { in NS class }\end{array}$ \\
\hline
\end{tabular}


This is an author-produced, peer-reviewed version of this article. The final, definitive version of this document can be found online at Canadian Journal of Economics. Published by Wiley on behalf of the Canadian Economics Association. Copyright restrictions may apply. doi: 10.1111/caje.12174

Table A2

Difference in difference estimates of the effect of being "young in class" on inattentive behaviour with interprovincial movers kept in sample

\begin{tabular}{|l|c|c|c|}
\hline & Boys+Girls & Boys & Girls \\
& OLS & OLS & OLS \\
\hline Young in Class & $0.415^{* *}$ & $0.509^{*}$ & $0.329^{* * *}$ \\
& $(0.135)$ & $(0.209)$ & $(0.064)$ \\
\hline Boy & $1.062^{* * *}$ & & \\
\hline Number of Observations & $(0.026)$ & & 12613 \\
\hline
\end{tabular}

Table A3a

Difference in difference estimates of the effect of being "young in class" on inattentive behaviour with each child randomly selected once

\begin{tabular}{|l|c|c|c|}
\hline & Boys+Girls & Boys & Girls \\
& OLS & OLS & $0.288^{* * *}$ \\
\hline Young in Class & $0.482^{* * *}$ & $0.680^{* *}$ & $(0.029)$ \\
\hline Boy & $(0.136)$ & $(0.235)$ & -- \\
& $1.064^{* * *}$ & & 8902 \\
\hline Number of Observations & $(0.039)$ & 9178 & \\
\hline
\end{tabular}

Appendix Table 3b

Regression discontinuity estimates with each child randomly selected once

\begin{tabular}{|l|c|c|}
\hline & Boys+Girls & Boys+Girls \\
& 2-month window & $0.691^{* * *}$ \\
\hline Young in Class & $0.756^{* * *}$ & $(0.212)$ \\
\hline Boy & $(0.252)$ & $0.863^{* * *}$ \\
& $0.854^{* * *}$ & $(0.085)$ \\
\hline Number of Observations & $(0.101)$ & 9039 \\
\hline
\end{tabular}


This is an author-produced, peer-reviewed version of this article. The final, definitive version of this document can be found online at Canadian Journal of Economics. Published by Wiley on behalf of the Canadian Economics Association. Copyright restrictions may apply. doi: 10.1111/caje.12174

TABLE A4

Example of provincial variation in construction of "young" variable for difference in difference estimates

\begin{tabular}{|l|l|l|l|l|l|l|}
\hline & September 1 & September 30 & October 31 & December 31 & End February & March 1 \\
\hline & Calgary & $\begin{array}{l}\text { Quebec and } \\
\text { Nova Scotia }\end{array}$ & PEI & $\begin{array}{l}\text { BC, SK, MB, } \\
\text { ON, NB, NL, } \\
\text { Other AB }\end{array}$ & Medicine Hat & Edmonton \\
\hline January & & & & & Young & Young \\
\hline February & & & & & Young & Young \\
\hline March & Young & & & & & \\
\hline April & Young & Young & & & & \\
\hline May & Young & Young & Young & & & \\
\hline June & Young & Young & Young & & & \\
\hline July & Young & Young & Young & Young & & \\
\hline August & Young & Young & Young & Young & & Young \\
\hline September & & Young & Young & Young & Young & Young \\
\hline October & & \multicolumn{1}{|l|}{ Young } & Young & Young & Young \\
\hline November & & & & Young & Young & Young \\
\hline December & & & & Young & Young \\
\hline
\end{tabular}

NOTE: This example table using the most recent school cut-off dates. As noted in Table 1, some changes in school cut-off dates have taken place during our study period.

Appendix Table 5

OLS Estimates of mother characteristics by child’s quarter of birth

\begin{tabular}{|l|c|c|c|c|}
\hline & University Degree & $\begin{array}{c}\text { Less than High } \\
\text { School }\end{array}$ & Married & Teen-Aged Birth \\
\hline Quarter One & -0.015 & 0.008 & $-0.018^{*}$ & 0.004 \\
& $(0.012)$ & $(0.009)$ & $(0.010)$ & $(0.004)$ \\
\hline Quarter Two & -0.009 & -0.010 & 0.006 & -0.004 \\
\hline Quarter Four & $(0.012)$ & $(0.008)$ & $0.010)$ & 0.002 \\
& $-0.023^{*}$ & 0.007 & $(0.011)$ & $(0.004)$ \\
\hline Number of & $(-0.012)$ & $(0.009)$ & 25413 & 25413 \\
Observations & 25413 & 25413 & & \\
\hline
\end{tabular}

NOTE: *** indicates statistically significant at $1 \%$; ** indicates statistically significant at $5 \%$; indicates statistically significant at $10 \%$. All models also control cycle. 
This is an author-produced, peer-reviewed version of this article. The final, definitive version of this document can be found online at Canadian Journal of Economics. Published by Wiley on behalf of the Canadian Economics Association. Copyright restrictions may apply. doi: 10.1111/caje.12174

Table A6

Regression discontinuity estimates of the effect of being "young in class" on inattentive behaviour of boys and girls at age $5 / 8$

\begin{tabular}{|l|c|c|c|}
\hline & $\begin{array}{c}\text { All Boys+Girls } \\
\text { Linear Running Variable, } \\
\mathrm{f}\left(\mathrm{bd}_{\mathrm{i}}-\mathrm{C}_{\mathrm{i}}\right),\end{array}$ & $\begin{array}{c}\text { All Boys+Girls } \\
\text { Quadratic Running Variable, } \\
\left(\mathrm{bd}_{\mathrm{i}}-\mathrm{C}_{\mathrm{i}}\right),\end{array}$ & $\begin{array}{c}\text { All Boys+Girls } \\
\text { Cubic Running Variable, } \\
\left(\mathrm{bd}_{\mathrm{i}}-\mathrm{C}_{\mathrm{i}}\right),\end{array}$ \\
\hline 2-month window & 4.118 & 4.118 & 4.118 \\
\hline Mean Score & $(3.027)$ & $(3.027)$ & $(3.027)$ \\
(St Deviation) & $0.501^{* *}$ & $0.503^{* *}$ & 0.308 \\
\hline Young in Class & $(0.243)$ & $(0.243)$ & $(0.329)$ \\
\hline Boy & $0.994^{* * *}$ & $0.994^{* * *}$ & $0.991^{* * *}$ \\
& $(0.108)$ & $(0.104)$ & $(0.104)$ \\
\hline + Covariates & $\mathrm{x}$ & $\mathrm{x}$ & $\mathrm{x}$ \\
\hline Number of Observations & 8127 & & 8127 \\
\hline 3-month window & & 4.099 & 4.099 \\
\hline Mean Score & 4.099 & $(3.026)$ & $(3.026)$ \\
(St Deviation) & $(3.026)$ & $0.532^{* *}$ & 0.440 \\
\hline Young in Class & $0.531^{* *}$ & $(0.206$ & $(0.270)$ \\
\hline Boy & $(0.207)$ & $0.940^{* * *}$ & $0.940^{* * *}$ \\
& $0.940^{* * *}$ & $(0.088)$ & $(0.088)$ \\
\hline + Covariates & $(0.088)$ & $\mathrm{x}$ & $\mathrm{x}$ \\
\hline Number of Observations & $\mathrm{X}$ & 12441 & 12441 \\
\hline
\end{tabular}

NOTE: These models also include grade, in a cubic specification, child gender, birth order, (log of) family income, parental education, family structure, immigrant status as well as province and NLSCY cycle. Robust standard errors clustering at distance from the cut-off are reported in parentheses. *** indicates statistically significant at $1 \%$; * indicates statistically significant at $10 \%$.

Table A7

Validity check for regression discontinuity models: estimated coefficient for young in regressions on each covariate

\begin{tabular}{|l|c|c|}
\hline Dependant Variable & $\begin{array}{c}\text { Coefficient on Young } \\
\text { Two-Month Window }\end{array}$ & $\begin{array}{c}\text { Coefficient on Young } \\
\text { Three Month Window }\end{array}$ \\
\hline Boy & 0.008 & 0.016 \\
& $(0.045)$ & $(0.037)$ \\
\hline PMK Immigrant & -0.011 & 0.047 \\
& $(0.042)$ & $(0.031)$ \\
\hline Log Equivalent Income & -0.034 & -0.029 \\
& $(0.046)$ & $(0.039)$ \\
\hline PMK University Education & 0.007 & 0.015 \\
& $(0.025)$ & $(0.019)$ \\
\hline PMK Diploma & 0.019 & 0.023 \\
& $(0.026)$ & $(0.020)$ \\
\hline PMK High School & 0.000 & 0.008 \\
& $(0.030)$ & $(0.023)$ \\
\hline Step Family & 0.005 & -0.006 \\
& $(0.014)$ & $(0.012)$ \\
\hline Lone-Parent Family & 0.008 & 0.009 \\
& $(0.028)$ & $(0.023)$ \\
\hline
\end{tabular}


This is an author-produced, peer-reviewed version of this article. The final, definitive version of this document can be found online at Canadian Journal of Economics. Published by Wiley on behalf of the Canadian Economics Association. Copyright restrictions may apply. doi: 10.1111/caje.12174

Table A8a

Robustness of OLS difference in difference estimates of the effect of being "young in class" on inattentive behaviour to alternative samples for boys

\begin{tabular}{|l|c|c|c|c|c|}
\hline & $\begin{array}{c}\text { Basic } \\
\text { Estimating } \\
\text { Sample }\end{array}$ & $\begin{array}{c}\text { Above Mean } \\
\text { Score }\end{array}$ & $\begin{array}{c}\text { Below Mean } \\
\text { Score }\end{array}$ & $\begin{array}{c}\text { Adding } \\
\text { Children not in } \\
\text { Public School }\end{array}$ & $\begin{array}{c}\text { Restricting to } \\
\text { Children } \\
\text { Observed } \\
\text { Since 3/4 }\end{array}$ \\
\hline $\begin{array}{l}\text { Mean Score } \\
\text { (St Deviation) }\end{array}$ & $\begin{array}{c}4.628 \\
(3.153)\end{array}$ & $\begin{array}{c}7.350 \\
(2.246)\end{array}$ & $\begin{array}{c}2.200 \\
(1.343)\end{array}$ & $\begin{array}{c}4.610 \\
(3.152)\end{array}$ & \\
\hline Young in Class & $0.503^{* *}$ & $0.515^{* * *}$ & 0.073 & $0.522^{*}$ & $0.512^{*}$ \\
$(0.214)$ & $(0.191)$ & $(0.085)$ & $(0.242)$ & $(0.231)$ \\
\hline Attended JK & & & & & 0.014 \\
& & & & & $0.050)$ \\
\hline $\begin{array}{l}\text { Attended Formal } \\
\text { Daycare at 3/4 }\end{array}$ & 12729 & 5939 & 6790 & 13279 & $(0.127)$ \\
\hline $\begin{array}{l}\text { Number of } \\
\text { Observations }\end{array}$ & & & & & 11640 \\
\hline
\end{tabular}

Table A8b

Robustness of OLS difference in difference estimates of the effect of being "young in class" on inattentive behaviour to alternative samples for girls

\begin{tabular}{|l|c|c|c|c|c|}
\hline & $\begin{array}{c}\text { Basic } \\
\text { Estimating } \\
\text { Sample }\end{array}$ & $\begin{array}{c}\text { Above Mean } \\
\text { Score }\end{array}$ & $\begin{array}{c}\text { Below Mean } \\
\text { Score }\end{array}$ & $\begin{array}{c}\text { Adding } \\
\text { Children not in } \\
\text { Public School }\end{array}$ & $\begin{array}{c}\text { Restricting to } \\
\text { Children } \\
\text { Observed } \\
\text { Since 3/4 }\end{array}$ \\
\hline $\begin{array}{l}\text { Mean Score } \\
\text { (St Deviation) }\end{array}$ & $\begin{array}{c}3.577 \\
(2.797)\end{array}$ & $\begin{array}{c}6.869 \\
(1.927)\end{array}$ & $\begin{array}{c}1.946 \\
(1.352)\end{array}$ & $\begin{array}{c}3.565 \\
(2.788)\end{array}$ & \\
\hline Young in Class & $0.337^{* * *}$ & 0.221 & 0.018 & $0.350^{* * *}$ & $0.245^{* * *}$ \\
$(0.059)$ & $(0.052)$ & $(0.040)$ & $(0.023)$ & $\begin{array}{c}0.032) \\
(0.079\end{array}$ \\
\hline Attended JK & & & & & $0.109)$ \\
\hline $\begin{array}{l}\text { Attended Formal } \\
\text { Daycare at 3/4 }\end{array}$ & & & & & $0.126)$ \\
\hline $\begin{array}{l}\text { Number of } \\
\text { Observations }\end{array}$ & 12467 & 4136 & 8331 & 13048 & 11401 \\
\hline
\end{tabular}


This is an author-produced, peer-reviewed version of this article. The final, definitive version of this document can be found online at Canadian Journal of Economics. Published by Wiley on behalf of the Canadian Economics Association. Copyright restrictions may apply. doi: $10.1111 /$ caje. 12174

Table A8c

Robustness of regression discontinuity estimates of the effect of being "young in class" on inattentive behaviour to alternative samples for boys+girls, using a 3-month window.

\begin{tabular}{|c|c|c|c|c|c|}
\hline & Full Sample & $\begin{array}{c}\text { Score Above } \\
\text { Mean }\end{array}$ & $\begin{array}{l}\text { Score Below } \\
\text { Mean }\end{array}$ & $\begin{array}{c}\text { Including } \\
\text { Children } \\
\text { Outside Public } \\
\text { School System }\end{array}$ & $\begin{array}{c}\text { Restricting to } \\
\text { Children } \\
\text { Observed } \\
\text { Since 3/4 }\end{array}$ \\
\hline $\begin{array}{l}\text { Mean Score } \\
\text { (St Deviation) }\end{array}$ & $\begin{array}{c}4.099 \\
(3.026) \\
\end{array}$ & $\begin{array}{c}7.147 \\
(2.122)\end{array}$ & $\begin{array}{c}2.049 \\
(1.353)\end{array}$ & $\begin{array}{c}4.087 \\
(3.022) \\
\end{array}$ & $\begin{array}{c}4.118 \\
(3.012) \\
\end{array}$ \\
\hline Young in Class & $\begin{array}{l}0.531^{* *} \\
(0.207)\end{array}$ & $\begin{array}{l}0.421^{* *} \\
(0.189)\end{array}$ & $\begin{array}{c}0.147 \\
(0.093)\end{array}$ & $\begin{array}{c}0.547 * * * \\
(0.208)\end{array}$ & $\begin{array}{l}0.337^{*} \\
(0.195)\end{array}$ \\
\hline Boy & $\begin{array}{c}0.940 * * * \\
(0.088)\end{array}$ & $\begin{array}{c}0.439 * * * \\
(0.097)\end{array}$ & $\begin{array}{c}0.188^{* * *} \\
(0.047)\end{array}$ & $\begin{array}{c}0.912 * * * \\
(0.090)\end{array}$ & $\begin{array}{c}0.946 * * * \\
(0.096)\end{array}$ \\
\hline Attended JK & & & & & $\begin{array}{l}-0.052 \\
(0.143)\end{array}$ \\
\hline $\begin{array}{l}\text { Attended Formal } \\
\text { Daycare at 3/4 }\end{array}$ & & & & & $\begin{array}{l}0.305^{* *} \\
(0.127)\end{array}$ \\
\hline $\begin{array}{l}\text { Number of } \\
\text { Observations }\end{array}$ & 12441 & 4943 & 7498 & 13025 & 11216 \\
\hline
\end{tabular}

Table A9

Rates of non-compliance with school entry regulations for children in Grades K through 4

\begin{tabular}{|l|c|c|c|}
\hline & Boys + Girls & Boys & Girls \\
\hline Newfoundland \% & 2.6 & 2.9 & 2.3 \\
\hline PEI \% & 0.0 & 0.0 & 0.0 \\
\hline Nova Scotia \% & 2.0 & 2.3 & 1.7 \\
\hline New Brunswick \% & 2.7 & 2.8 & 2.6 \\
\hline Quebec \% & 1.5 & 1.5 & 1.4 \\
\hline Ontario \% & 2.6 & 2.4 & 2.7 \\
\hline Manitoba \% & 2.3 & 1.5 & 3.0 \\
\hline Saskatchewan \% & 0.0 & 0.0 & 0.0 \\
\hline Alberta \% & 0.0 & 0.0 & 0.0 \\
\hline BC \% & 2.4 & 3.0 & 1.6 \\
\hline
\end{tabular}


This is an author-produced, peer-reviewed version of this article. The final, definitive version of this document can be found online at Canadian Journal of Economics. Published by Wiley on behalf of the Canadian Economics Association. Copyright restrictions may apply. doi: 10.1111/caje. 12174

Table A10

Covariate means for our basic estimating sample of children aged 5 to 8 in public schools

\begin{tabular}{|c|c|c|c|}
\hline & Boys+Girls & Boys & Girls \\
\hline \multicolumn{4}{|l|}{$\begin{array}{c}\text { Mean } \\
\text { (St Deviation) }\end{array}$} \\
\hline Young in Class & $\begin{array}{c}0.503 \\
(0.500)\end{array}$ & $\begin{array}{c}0.496 \\
(0.500)\end{array}$ & $\begin{array}{c}0.510 \\
(0.500)\end{array}$ \\
\hline Boy & $\begin{array}{c}0.506 \\
(0.500)\end{array}$ & 1.0 & 0.0 \\
\hline First-Born & $\begin{array}{c}0.455 \\
(0.498)\end{array}$ & $\begin{array}{c}0.463 \\
(0.499)\end{array}$ & $\begin{array}{c}0.446 \\
(0.497)\end{array}$ \\
\hline Born First Quarter & $\begin{array}{c}0.262 \\
(0.440)\end{array}$ & $\begin{array}{c}0.266 \\
(0.442)\end{array}$ & $\begin{array}{c}0.258 \\
(0.437)\end{array}$ \\
\hline Born 2nd Quarter & $\begin{array}{c}0.271 \\
(0.445)\end{array}$ & $\begin{array}{c}0.270 \\
(0.444)\end{array}$ & $\begin{array}{c}0.272 \\
(0.445)\end{array}$ \\
\hline Born 4th Quarter & $\begin{array}{c}0.208 \\
(0.406)\end{array}$ & $\begin{array}{c}0.204 \\
(0.403)\end{array}$ & $\begin{array}{c}0.217 \\
(0.408)\end{array}$ \\
\hline Equivalent Household Income & $\begin{array}{c}37,980 \\
(25,200)\end{array}$ & $\begin{array}{c}38,175 \\
(25,761)\end{array}$ & $\begin{array}{c}37,779 \\
(24,611) \\
\end{array}$ \\
\hline PMK University & $\begin{array}{c}0.228 \\
(0.420)\end{array}$ & $\begin{array}{c}0.231 \\
(0.421)\end{array}$ & $\begin{array}{c}0.226 \\
(0.418)\end{array}$ \\
\hline PMK College Diploma & $\begin{array}{c}0.269 \\
(0.443)\end{array}$ & $\begin{array}{c}0.281 \\
(0.450)\end{array}$ & $\begin{array}{c}0.254 \\
(0.436)\end{array}$ \\
\hline PMK High School & $\begin{array}{c}0.403 \\
(0.491)\end{array}$ & $\begin{array}{c}0.386 \\
(0.489) \\
\end{array}$ & $\begin{array}{c}0.421 \\
(0.494) \\
\end{array}$ \\
\hline Step Family & $\begin{array}{c}0.047 \\
(0.212)\end{array}$ & $\begin{array}{c}0.048 \\
(0.213)\end{array}$ & $\begin{array}{c}0.047 \\
(0.212)\end{array}$ \\
\hline Lone Parent Family & $\begin{array}{c}0.165 \\
(0.371)\end{array}$ & $\begin{array}{c}0.168 \\
(0.374)\end{array}$ & $\begin{array}{c}0.162 \\
(0.368)\end{array}$ \\
\hline PMK Immigrant & $\begin{array}{c}0.163 \\
(0.369)\end{array}$ & $\begin{array}{c}0.162 \\
(0.369)\end{array}$ & $\begin{array}{c}0.163 \\
(0.369)\end{array}$ \\
\hline Child Age in Months & $\begin{array}{c}81.0 \\
(14.5)\end{array}$ & $\begin{array}{c}81.0 \\
(14.4)\end{array}$ & $\begin{array}{c}81.0 \\
(14.5)\end{array}$ \\
\hline Number of Observations & 25196 & 12729 & 12467 \\
\hline
\end{tabular}


This is an author-produced, peer-reviewed version of this article. The final, definitive version of this document can be found online at Canadian Journal of Economics. Published by Wiley on behalf of the Canadian Economics Association. Copyright restrictions may apply. doi: 10.1111/caje.12174

Appendix Table 11. Overlap between behavioural scales and CDC DSM-IV criteria for ADHD

\begin{tabular}{|c|c|c|}
\hline NLSCY & ELDER Parent Scales & ELDER Teacher Scales \\
\hline & P1Learn & T1 Learn \\
\hline *Is inattentive & * Attentiveness & * Attentiveness \\
\hline \multirow{5}{*}{$\begin{array}{l}\text { * Is easily distracted, has trouble } \\
\text { sticking to any activity }\end{array}$} & $*$ Task Persistence & * Task Persistence \\
\hline & Eagerness to Learn & Eagerness to Learn \\
\hline & * Learning Independence & * Learning Independence \\
\hline & Flexibility & Flexibility \\
\hline & * Organization & * Organization \\
\hline \multicolumn{3}{|l|}{$\begin{array}{l}\text { * Can't concentrate, can't pay } \\
\text { attention for long }\end{array}$} \\
\hline & P1 Impuls & \\
\hline * Can't sit still is restless & * Is Very Active & \\
\hline \multicolumn{3}{|l|}{$\begin{array}{l}\text { * Can't settle to anything for more } \\
\text { than a few minutes }\end{array}$} \\
\hline \multicolumn{3}{|l|}{$\begin{array}{l}\text { * Has difficulty waiting for his turn } \\
\text { in games or groups }\end{array}$} \\
\hline \multirow[t]{24}{*}{ * Is impulsive, acts without thinking } & $*$ Acts Impulsively & \\
\hline & P1Control & T1Extern \\
\hline & & * Acts Impulsively \\
\hline & Argues & Argues \\
\hline & Fights & Fights \\
\hline & Gets Angry & Gets Angry \\
\hline & Throws Tantrums & Disturbs Ongoing Activities \\
\hline & & T1Control \\
\hline & & Respect others property \\
\hline & & Controls Temper \\
\hline & & $\begin{array}{l}\text { Accepts Peer Ideas for Group } \\
\text { Activities }\end{array}$ \\
\hline & & $\begin{array}{l}\text { Responds Appropriately to Peer } \\
\text { Pressure }\end{array}$ \\
\hline & P1Social & T1 Interp \\
\hline & Making/Keeping Friends & Forming/Maintaining Friendships \\
\hline & Ease in Joining Play & $\begin{array}{l}\text { Getting Along with People who are } \\
\text { Different }\end{array}$ \\
\hline & Positive Interactions with Peers & Comforting/Helping other Children \\
\hline & & $\begin{array}{l}\text { Expressing Feelings in Positive } \\
\text { Ways }\end{array}$ \\
\hline & & Sensitivity to Feelings of Others \\
\hline & P1Sadalone & T1Intern \\
\hline & & Anxiety \\
\hline & Loneliness & Loneliness \\
\hline & Low Self Esteem & Low Self-Esteem \\
\hline & Sadness & Sadness \\
\hline & $\begin{array}{l}\text { Problems with being } \\
\text { Accepted/Liked by Others }\end{array}$ & \\
\hline
\end{tabular}

